LESSONS FROM THE EXPANSION OF THE UPPER SECONDARY EDUCATION FOR THE EXPANSION OF THE TERTIARY EDUCATION

Miroslav BeblaVÝ, MARCELA VeSELKOVÁ, NICOLA PENSIERO, ELIN PETERSON, ANNAELISABETH THUM AND SIMON TOUBEAU NEUJOBS WORKING PAPER NO. 4.4.1 JULY 2012

Abstract

In this paper, we present the historical time series of enrolment rates in upper secondary schooling in five European countries. The presented data were examined in light of reform attempts aimed at expansions of schooling with the aim to derive lessons for the expansion of the tertiary sector. We were particularly interested in the speed and the differentiation of the expansion. We find that the expansion happened at different speed. It took 9 to 26 years for a country to massify its upper secondary education and further 11 to 41 years to universalize it, with gross enrollment rates reaching $80 \%$. The expansion was slower in the leaders of expansion, such as the United Kingdom or Sweden. In contrast, laggards were able to catch up relatively fast, once the limiting conditions of expansion were removed. Although there has been a general trend towards expansion of the general upper secondary education, the popularity of vocational tracks has been diverse across examined countries. 
2 | BEBLAVY, VESELKOVA, PENSIERO, PETERSON, THUM AND TOUBEAU
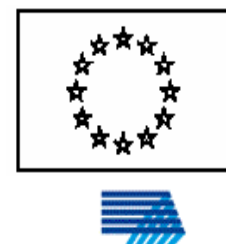

SEVENTH FRAMEWORK

PROGRAMME

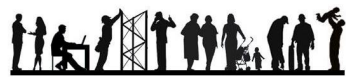 \\ NEUJOBS}




\section{CONTENTS}

1. Introduction, p. 1

2. Theoretical Insights into Expansion of Educational System, p. 2

3. Methodology, p. 5

4. Expansion of Upper Secondary Schooling from the Historical Perspective, p. 7

5. Conclusions, p. 17 



\title{
LESSONS FROM THE EXPANSION OF THE UPPER SECONDARY EDUCATION FOR THE EXPANSION OF THE TERTIARY EDUCATION
}

\author{
MIROSLAV BEBLAVÝ, MARCELA VESELKOVA, NICOLA
}

PENSIERO, ELIN PETERSON, ANNA-ELISABETH THUM

AND SIMON TOUBEAU*

NEUJOBS WORKING PAPER NO. X/DATE

\section{Introduction}

In light of the widespread recognition that higher education is crucial for economic development and job creation, the European Union agreed the target that at least 40 percent of 30-34-year-olds should have a higher education qualification or equivalent by 2020. In $2009,32.3 \%$ of $30-34$ year olds in the EU had tertiary attainment, compared to only $22.4 \%$ in 2000 (European Commission 2011: 68). Eleven EU countries had already exceeded the 2020 target (European Commission 2011: 68). In contrast, the lowest completion rates could be found in the Southern and Central European countries, despite the fact that they have very high secondary education completion rates.

Expansion of the tertiary education is a novel development. Since the establishment of the first university in the eleventh century until the World War II, the university education had been reserved for small elite. In the 1950s, undergraduate students accounted for a mere 3\%-5\% of their relevant age group in Europe (Davidovitch et al. 2012: 102). These low figures reflected low enrolment rates in academic upper secondary tracks, which similarly to the higher education were reserved to only few. Expansion of the tertiary education had to be therefore preceded by the expansion of the upper secondary sector. The United States led all other nations in the development of the universal and publicly funded secondary education. From 1910 to 1940, the high school enrollment rate rose from 18 percent to 73 percent and the graduation rate increased from 9 percent to 51 percent (Goldin 1998: 347). Other industrialized countries with per capita incomes similar to that of the United States, particularly European economies, experienced their high school movements thirty or more years later. But whereas the U.S. "high school movement" was a grass-roots phenomenon, expansion of upper secondary education was a top-down project in Europe. After the World War II, European governments actively sought to expand the upper secondary education and make it available to the masses. The gross enrollment ratio in Europe

\footnotetext{
* Miroslav Beblavý, Centre for European Policy Studies, Brussels. Marcela Veselkova, Slovak Governance Institute, Bratislava. Nicola Pensiero, European University Institute, Florence.

Elin Peterson, Complutense University of Madrid.

Anna-Elisabeth Thum, Centre for European Policy Studies, Brussels.

Simon Toubeau, Centre for European Policy Studies, Brussels.

We are grateful for the research assistance of Galina Potjagailo.
} 
passed $80 \%$ threshold around 1975 and can be thus considered universal. During the last decades the increase in upper secondary enrolment has slowed down, indicating that a point of saturation might have been reached.

As the (1) completion of the upper secondary education is a pre-requisite for a tertiary education, and (2) the expansion of the upper secondary schooling has reached its upper limits, the study of the expansion of the secondary education can be instrumental for understanding the dynamics and limits underlying the expansion of tertiary education. In this paper, we therefore ask three interrelated questions: (1) how fast the upper secondary sectors expanded, (2) which tracks benefited from the expansion, and (3) whether expansion reflected policies aimed at expansion. To answer these questions, we construct a historical time series of enrolment rates in Czechoslovakia, Spain and the United Kingdom. Our comparative case study is supplemented by the existing historical time series of Germany and Sweden. We cover the post-World War II period, which witnessed the most rapid expansion of European upper secondary education.

The rest of the paper is organized as follows. The next section reviews the existing literature on the educational expansion. The third section discusses our methodology. The fourth section discusses the national case studies from the comparative perspective. The final section summarizes our findings.

\section{Theoretical Insights into Expansion of Educational Systems}

At this point, we would like to emphasize that our paper is not a theory-testing paper and its scope is limited by a set of clearly defined empirical questions. Nevertheless, the above review of literature enables us to sketch a mental map that will guide us through a vast amount of available empirical material. Although our analysis is driven by empirical curiosity, we would like to briefly discuss the existing theoretical explanations of dramatic worldwide expansion of national educational systems in the post-World War II period. These can be divided into functionalist, sociological and institutionalist explanations.

The socioeconomic functionalism suggests that national economic development creates collective and individual demand for specialized training. On the supply side, economic development also creates the resources to meet these ends (see Collins 1971, Goldin 1998). Higher education can be seen as a consumption good in societies where basic need have been met. However, the evidence for the functionalist explanations of expansions if mixed. No strong effects of national industrialization or economic development on expansion of education at any level (Meyer et al 1977, 1992b, Windolf 1997).

Whereas the functionalist explanations emphasize the role of the market forces in expansion of educational systems, theories of conflict, competition and organization shift attention to the social status role of education. Groups and individuals compete to success in education, producing inflationary credential expansion beyond any original functional requirements (Bourdieu and Passeron 1977, Collins 1971, 1979). Elite groups use education to perpetuate the dominance of their status-group. Education expansion 
should be therefore more rapid (and less functional) when status group competition is high (Rubinson and Fuller 1992). However, these theories are more likely to explain content rather than the expansion of education.

Finally, institutionalist explanations emphasize the role of global factors or integrated transnational culture, to which nation-states converge: Nation- states expand schooling because they adhere to world models of the organization of sovereignty (the modern state) and the organization of society as composed of individuals (the modern nation)." (Meyer et al. 1992: 129, see also Ramirez and Boli 1987).

The fact that there is more change and variation in educational organization than institutionalists seem to acknowledge became a source of critique (see Meyer and Rowan 2006b; Levy 2006; Marshall and Anderson 1994; Crowson 1996). The institutional analysis of Meyer and his colleagues in the late 1970s and early 1980s saw education as fully controlled by government. However, the monopoly of state as the provider of the education has eroded and we witness an increasing "privatization of the public sphere" (Marshall and Anderson 1994: 177, Meyer and Rowan 2006b: 2). Expansion of the private sector is thus able to undermine the ability of policy-makers to manage the expansion of educational systems.

In addition to the expansion of the schooling, it is vital to examine also the differentiation of the schooling. During the past 60 years, the relative share of vocational education declined. It is also important to note the difference between the Western and Eastern Europe. Until the collapse of the communism there was a high proportion of vocational over general education in Eastern Europe due to the nature of the school reforms introduced by the communist regimes, which for ideological reasons greatly emphasized the role of vocational education (Bertocchi and Spagat 2004: 580582). In the 1990s the ratio converged to Western European values.

The functionalist approaches emphasize the role of the technology: the initial rise of vocational education reflects the rising labor market demand for related skills. As already discussed in the introduction the literature fails to establish a link between the demand for specific skills and the supply of these skills (see Collins 1971). In contrast, the conflict approaches understand curriculum differentiation as a way for the elite group to preserve its position by directing educational expansion into vocational education (Weber 1921, Neelsen 1975). Bertocchi and Spagat (2004) attempt to combine these two approaches and emphasize the role of distributional conflict and political change in the shaping of educational system. In their model, the median voter will want his children to enter general high school, while excluding the children of everyone poorer than himself. Therefore, in the first stage of economic development the size of the vocational sector relative to the general sector increases. At the later stage, the lower class wealth levels cross the voting threshold and the political equilibrium generates a general sector that expands relative to the vocational one. Finally, the global factors may play an important role in the differentiation of curricula. As secondary education expands and becomes an extension of mass elementary education, it comes under the influence of standard world models linking education with notions of social

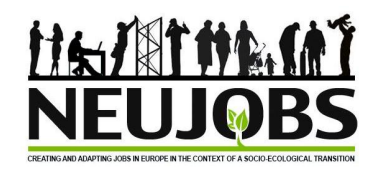


and economic progress (Kamens et al. 1996: 117). These standard world models stress comprehensive and general forms of secondary education rather than highly differentiated curricular programs (Benavot 1983: 63-67).

Historically, the secondary education in Europe was rooted in the classical curricula and aimed to train elites (see Kamens et al. 1996). In response to the movement to expand educational opportunities for the middle and working classes, the classical curricula transformed into specialized mathematics and science or arts, humanities and modern languages curricula. In contrast, comprehensive curricula combine diverse educational purposes, such as occupational training and university preparation and serve students from various socioeconomic backgrounds. They developed in countries that lacked a stable, elite political class, such as the United States. As comprehensive curricula entail lower start-up costs and provide greater flexibility, they are popular also in the Third World countries.

The vocational curricula evolved from apprenticeship (see Benavot 1983). In response to industrialization various agencies, such as private industries, town councils and industrial associations, initiated policies to control and standardize job training process. Vocational courses were introduced into public schools. These programs were supported by private factorites trying to minimize training costs, as well as states that tried to promote economic development. However, the process of industrialization in Europe did not result in a standardized model of vocational training. Instead, it gave rise to three vocational models. In the market model of vocational training - characteristic of England - the relationship between training needs and training provision was governed by the market. Common standards of training were absent and the costs were covered individually, usually by learners. In the state bureaucratic model - first introduced consistently in France - workers are 'skilled' with the help of a state-regulated and statefunded education sector. Finally, in the dual corporatist model - implemented in the German cultural area - the vocational training is largely isolated from general education. The key place of learning is the enterprise.

Interestingly, the publicly funded vocational training predated the publicly funded general secondary education. Whereas England, France, Germany, Belgium, Switzerland and the Netherlands all passed legislation providing for publicly funded vocational instruction in either separate vocational schools or dual-stream secondary schools by the 1920s (Gregoire 1967: 15-32), the law that guaranteed a tuition-free secondary school education for all British children was passed only in 1944 (Goldin and Katz 1998: 6).

During the post-WWII expansion of postprimary education many vocational training programs on the secondary level were introduced. The development of vocational training was advocated and supported also by specialized transnational agencies, such as the International Labour Office and UNESCO. In the mid-1960's, the share of World Bank loans for vocational programs in developing countries was the same as for general ones (over 40 percent of total educational funding) (Psacharopoulos1980:11). By the late 1970's, loan allocation had increased to a point where technical/vocational

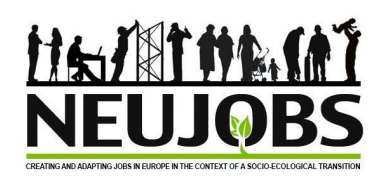


programs received over one-half of all funding (53 percent) while general programs received only one-third (ibid). The importance of the vocational training was acknowledged also by the Community. Article 128 of the Treaty of Rome states that a common policy for vocational training should be developed. However, this policy has never come to fruition, largely due to resistance from Germany and France (Petrini 2004). These countries already possessed highly developed vocational training systems and were not keen to take on the costs of retraining the southern Italian labor force.

\section{Methodology}

Our historical, comparative case study relies on several means. First, we created a historical database of gross enrolment rates at all levels of study. Our dataset covers the post-World War II period, which witnessed a rapid expansion of European upper secondary education. The presented data are complemented by the literature reviews and an analysis of policies, which aimed to influence the expansion of the upper secondary schooling.

The long time span limited our methodological choices. Due to the data availability, we measure expansion by gross enrollment ratio. Gross enrolment rates are calculated as the share of all students enrolled in a certain school level or track, relative to the total population in the official age group for the respective education level in percent. The rate thus provides information about the number of students to those who qualify for the particular grade level. It is important to notice that the gross enrolment rates can exceed 100, due to repeaters or adult learners. The main advantage of this measure is that it includes adult learners.

In case of Czechoslovakia, Spain and the United Kingdom, we gathered original datasets from the national statistical sources. We disregarded using existing international datasets, such as UNESCO's historical time series, Banks (1973) or Mitchell's (2005) Historical Statistics for two reasons. First, the definitions of lowerand upper-secondary schooling made it difficult to compare data across countries and/or over time. For example, UNESCO tended to define lower secondary education as primary education in the 1950s and as the secondary education after 1975. Similar problems were observed in the widely used Mitchell's dataset upon comparison with the data gathered from the national sources. Second, by gathering our own data, we were able to take a more detailed look at the expansion of the upper secondary schooling by the level of the study or by the division into general and vocational tracks. However, one should bear in mind that differences among educational systems, numerous reorganizations of schooling systems over the past six decades and changes in the data gathering methodology make it problematic to compare our data across countries and over time as well. Nevertheless, we believe that by paying close attention to national specificities, we are able to paint an accurate and informed picture of the expansion of the upper secondary education. In case of Germany and Sweden, we used existing datasets, namely Bundesministerium fuer Bildung und Forschung (BMBF), Statistisches Bundesamt, Koehler $(1978,1990)$ and EUROSTAT and de la Croix, Lindh and Malmberg (2006) and Statistics Sweden (2011, 2012), respectively.

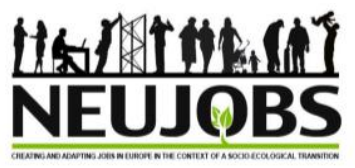


When looking on educational systems across Europe, one can distinguish among different educational models, followed by different countries depending on their cultural and historical backgrounds. These different educational models also imply different educational structures and policies, possibly having contrasting impacts on enrolment rates in upper secondary education and tertiary education. To answer our research questions, we therefore rely on a comparative study of five European countries, namely Sweden (Peterson 2012), Germany (Thum 2012), United Kingdom (Toubeau 2012), Czechoslovakia (Veselkova 2012) and Spain (Pensiero 2012).

The case selection was based on several criteria. First, we were interested in equality of educational opportunities. There is a growing body of literature, which suggests that the sooner the students are tracked (or selected) into different school types, hierarchically structured by performance, the greater the dependence of the student performance on family background (Hanushek and Woessmann 2006, Pfeffer 2008, Schuetz et al. 2008, OECD 2004, 2007, 2010, Woessmann 2009). In case of highly stratified educational systems, i.e. system characterized by early tracking and low mobility between tracks, the future of the child may be decided as early as the age of 10. Such systems hamper the chances of children from lower socio-economic background to achieve tertiary attainment. Expansion of the upper secondary and tertiary education thus does not have to be necessarily associated with higher equality of educational opportunities. We choose Sweden and Germany as two countries located at the opposing poles of the stratification dimension (Pfeffer 2009). Whereas German students are selected at the age of 10, Swedish students are educated in comprehensive schools up until the age of 16. Furthermore, the concept of the lifelong learning is particularly strong in Sweden.

The United Kingdom features a distinct education model which, unlike continental countries, was not managed in a hierarchical fashion by a central bureaucracy, but rather, by civil society and local political entities. This characteristic has meant that the country presents a complex education structure, exhibiting important differences between public and private provision, but also considerable diversity within the public sector.

The case of Czechoslovakia represents the specific experience of communist countries, in which expansion of the upper secondary education was heavily supported by the central government. However, the support for the expansion of the tertiary education was limited due to political concerns. Furthermore, the general to vocational ratio was kept artificially low. The regime change and the liberalization of the education market thus provide an opportunity to examine how fast the suppressed educational systems catch up with the Western countries.

Finally, the expansion of the upper secondary schooling in Spain has been associated with high extremely high dropout rates. Between 2000 and 2009, the dropout rates in Spain jumped to $31.2 \%$. This is significantly exceeds the Europe 2020 target of 10 percent. The increase in dropout rates triggered the debate on the risks that some students are neither sufficiently competent nor motivated to cope with the basic curriculum for all students to the age of 16 (Marchesi 1992: 597). 


\section{Expansion of Upper Secondary Schooling from the Historical Perspective}

At the end of the World War II, the upper secondary sector was small. Most of youth was educated in vocational schools or entered the labor force. General, academic programs leading to university studies were available for few, mostly the children from families with high socio-economic status. In response to the growing societal demand for upper secondary schooling and the demands of industrializing societies, European governments embarked on the radical reforms of educational schooling, which would make upper secondary schooling available to the masses. However, this process was not uniform across Europe. National educational systems began to expand at a different time and with a different speed.

\subsection{Speed of expansion}

In case of speed of the expansion, we set two hypothetical benchmarks: massification of education characterized by a transition from $20 \%$ to $50 \%$ gross enrollment rates and universalization of education characterized by a transition from $50 \%$ to $80 \%$ gross enrollment rates (Trow 2005: 64 sets the boundaries as 15\% for a transition from elite to mass and $50 \%$ as a transition from mass to universal.). Our results are summarized in Table 1.

Table 1: Increase in gross enrollment rates in the upper secondary education

\begin{tabular}{|c|c|c|c|c|}
\hline & From 20 to 50\% & Period & From 50 to 80\% & Period \\
\hline Czechoslovakia & --- & --- & 19 & $1958-1977$ \\
\hline Slovakia & 14 & $1948-1962$ & 16 & $1962-1978$ \\
\hline Germany & NA & & NA & \\
\hline Spain & 9 & $1962-1971$ & 11 & $1971-1982$ \\
\hline Sweden & 10 & $1937-1947$ & 41 & $1947-1988$ \\
\hline UK & 26 & $1948-1974$ & 26 & $1974-2000$ \\
\hline
\end{tabular}

Source: Authors.

It took 9 to 26 years for a country to massify its upper secondary education and further 11 to 41 years to universalize it, with gross enrollment rates reaching $80 \%$. Although the data should be interpreted with caution due to differences in the organization of national schooling systems, it is clear that countries expanded their upper secondary sectors at various speed. The expansion was slower in the leaders of expansion, such as the United Kingdom or Sweden. In contrast, laggards were able to catch up relatively fast, once the limiting conditions were removed.

Among the countries examined in this study, Spain was the latest country to expand the upper schooling sector, mostly due to the specific features of the Franquist regime (see Figure 1). The schooling sector was controlled by the Catholic Church. The enrolment to academic upper secondary bachillerato was halted by high enrolment fees and therefore available mostly to the well-off families. The elitism enabled to reproduce the existing social stratification and this way concentrate the power in the hands of the 
ruling elite. Furthermore, the expansion of the upper secondary sector is costly. In order to minimize the burden of welfare financing bore by upper class, the taxation under the Franco rule was very low. As a result, the spending on the schooling was held at approximately one third of expenditures in the most developed European countries, such as Germany or France.

Once these constraints were removed, the enrollment in upper secondary schooling quickly caught up with other European countries. When the Spanish educational system was reorganized in 1970, the enrollment in the upper secondary sector reached $48.13 \%$. By the socialist reforms of 1982, the upper secondary sector expanded to $75.06 \%$. In 1982 , the gross enrollment rates jumped to $88.21 \%$. The Spanish upper secondary sector thus became universal within a decade.

Fast process of catching up in response to policies aimed at expansion of the upper secondary schooling was documented also in case of Czechoslovakia (see Figures 2-3). Prior to the communist reform of 1948, only about one-quarter of the Czechoslovak population progressed from primary to secondary schools, which culminated in a "maturita" exam needed for an entry to the university. Furthermore, there was a significant regional difference in gross enrollment rates $-45 \%$ in the Czech lands and $21 \%$ in Slovak lands. Within five years from the reform, the gross enrollment rates rose to $52 \%$ in the Czech lands and to $36.5 \%$ in the Slovak lands. The gross enrollment in the upper secondary education reached universal levels of $80 \%$ in both regions by 1978 . In other words, the upper secondary education was universalized within three decades in both regions despite different starting points. However, one should bear in mind that educational achievement was often of questionable quality, as the regime enabled workers to graduate under simplified circumstances. For example, for a certain time workers were able to obtain "maturita" certificate for general upper secondary education in a year. This suggests that the data on educational attainment should be analyzed with caution.

In contrast to the Spanish and Czechoslovak experience, expansion of upper secondary sector in Germany focused mostly on the expansion of the small general sector (see Figures 4-5). Enrolment rates for vocational education were already high at the beginning of the $1950 \mathrm{~s}$, reaching the value of $86 \%$. In the following decades, part of the age cohort moved to the general programs. By 2009, the gross enrollment rates in gymnasia grew almost tenfold, reaching almost 40\%. About half of this increase happened between 1950 and 1975 and another half during the subsequent 35 years. Since the 1980s, enrolment rates in the vocational education have been increasing steadily.

The expansion of the upper secondary schooling began after the World War I and accelerated after the World War II (see Figure 6). In 1945, the enrolment rate in Swedish upper secondary education was 43.5\%. The year of the 1960 Education Act, which established the 9 year compulsory primary school, the enrolment rate had risen to $52.8 \%$. By 1968 with the adoption of the upper secondary school reform and the replacement of parallel schools with the integrated gymnasieskolan the enrolment had increased to $63.6 \%$. In 1980 the enrolment rate shows practically universal participation in upper secondary education, $80.3 \%$, although the enrolment rate would go down during this decade. The 1991 education reform involved the full universalization of

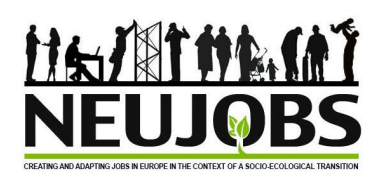


upper secondary education with municipalities obliged by law to offer upper secondary education to all young people between 16 and 20 who had finished primary education. In 1991 the enrolment rate was $88.0 \%$ and ten years later the enrolment rate was $100 \%$ and even more due to the number of older students making up for upper secondary education, often with the aim of continuing to tertiary studies. The percentage of upper secondary student enrolments in vocational tracks has shifted since the 1991 reform, and increased in the last decade: $49 \%$ in 1992, 41\% in 1998, 53\% in 2005 and $55 \%$ in 2009 (OECD 2011; Kuczera et. al. 2008).

Finally, the expansion of the secondary education in the United Kingdom happened in several waves (see Figure 7). During the 1940s and early 1950s, the size of the student body in upper secondary tracks was around 10 percent of the population in the relevant age category (15-18); 2 percent of which were in private (independent) schools, the rest of which were in selective grammar schools. The gross enrolment rate then grew gradually by about 10 percent every decade, reaching 32 percent by 1970 . There is a very notable leap in the NER in 1973, from 28 percent to 44 percent, following the extension of the CLA from 15 to 16. This increased the NER to around 40 percent for the remainder of the period. After completing the compulsory education, those students who do not continue their education in the secondary sector may decide to enroll to one of the institutions of the further education, such as sixth form colleges. In the age cohort 16-18 years, the grosss enrolment rate in the further education expanded from $6.6 \%$ in 1947 to $45.6 \%$ in 2009. This implies that the gross enrolment in upper secondary and corresponding further education programs is universal. For the comparison, the gross enrolment rate in all upper secondary programs reached almost 97\% in 2009 (World Bank, Education - Data and Statistics).

The universalization of the upper secondary schooling is a prerequisite for the expansion of the tertiary schooling, as it increases the pool of students eligible for the tertiary study. In all examined countries, the tertiary enrolment began to rise sharply as the enrolment in upper secondary tracks was approaching universal levels. However, one should bear in mind that not all upper secondary tracks enable enrolment to the tertiary studies. The national certification of graduates may mediate the impact of the expansion of the upper secondary schooling on the higher education. Typically, general, academic programs lead to certificates that enable entry to the tertiary studies. Expansion of general programs was therefore more important for the expansion of tertiary education. Over time, policy makers - eager to increase equality of educational opportunities - tried to remove educational dead-end pathways by increasing the mobility between the general and vocational tracks and introduction of intermediate schools, which would enable students to get to universities even from vocational schools.

\subsection{Direction of Expansion}

The expansion of upper secondary schooling was directed mostly to general tracks, which are usually viewed as a preparation for higher education, with a single exception of Germany (see Figure 8). There the large vocational sector initially declined relatively to the general track but since the 1980s, both tracks expanded simultaneously. We

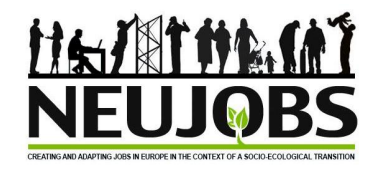


attribute this development to the strong tradition of the apprenticeship in Germany and to the introduction of new intermediate forms of educational institutions, which can be situated between the traditional Gymnasium and the classical 'dual system' of part-time vocational schools combined with apprenticeship training in companies, such as the technical Gymnasium or full-time vocational schools. Alternatively, the high protection of skills in coordinated market economies serves as an incentive for workers to invest in specific, vocational skills (Estevez-Abe et al. 2001).

There have been numerous attempts to manage expansion of the upper secondary schooling into concrete tracks. In some countries, such as Sweden, Spain or the United Kingdom, general and vocational tracks were gradually brought closer. Majority of students is educated in comprehensive schools up to the age of 16. As a result, it was easier to get a placement in academic programs of upper secondary school than in vocational school in Sweden since 1970s. In contrast, the vocational schools in the postcommunist Czech Republic and Slovakia remained empty (see Figures 9-10). Following the collapse of the communism, there were several political declarations about the need to expand the general sector. These, however, were not translated into concrete policies. Nevertheless, expansion of the general schooling did occur through the working of the market forces (see below).

The Swedish data on the distribution of pupils between academic and vocational tracks is difficult to compute and should be interpreted with caution (see Figures 11-12). For instance, in the academic and vocational study programmes (linjer) there were up to 90 possible variations (Opper 1989: 140). The figure below depicts the trends in upper secondary level graduates 1972-1999. It shows the number of graduates from upper secondary school study programmes from the 2-year vocational programmes, the three and four year theoretical programmes and the two year theoretical programmes (estimates after 1985 are based on the government's budget proposal of 1984/85). Opper argues that the following rough estimates can be obtained from her data: approximately half the students in the relevant cohort (18 year olds) graduated from two-year vocational study programmes, a third from long academic programmes, and the remainder from two-year academic programmes or specialized courses.

The enrolment in the Spanish academic bachillerato is considered excessive (OECD 2008). Although there was a shift from bachillerato to vocational training throughout the 1970s - 90\% of students were attending bachillerato in 1970 while in 1980 they were $67 \%$ - up to the mid-1990s, the percentage of pupils choosing bachillerato kept slowly decreasing, then from 1996 it started to rise again and reached its peak in 2002. A new decline in preferences for bachillerato occurred from 2003 to 2008 (see Figure 13). The teachers' guidance is cited as one of the factors responsible for high bachillerato enrollment rates, as teachers tend to favor of academic studies.

The distribution of students across tracks in the United Kingdom must be analyzed in waves corresponding to the major reforms of educational system (see Figure 14). The first period (1948-1964), corresponds to the 'tripartite' system established by the 1944 Education Act, in which the public or maintained system consisted of modern, technical and grammar schools. The modern schools were designed for the majority of pupils, i.e.

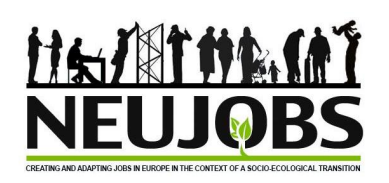


those who did not achieve scores in the top $25 \%$ of the eleven plus examination. In the late 1940s, they took in around 20 percent of pupils, a figure which rose to 30 percent by the early 1960s. Grammar schools took in around 12 percent in the late 1940s, a figure that remained constant over the same period, reflecting the fixed number of schools and places; technical schools were also established but were never popular, attracting at their apex in 1957 only 2.5 percent of pupils. Private or independent schools experienced a slight increase during the 1950s, from 2 to 5 percent, and then stabilized at around 4 percent until the late 1960s.

The period of 1965-1979 corresponds to the development of the 'comprehensive' system, ushered in by the Labour government with the 1965 Circular. Enrollment in comprehensive schools grew in two stages: between 1965 and 1973, the gross enrolment increased from 4 to 24 percent, and then from 1973 to 1979, it continued to increase from 24 to 47 percent, experiencing a massive leap in 1974 from 24 to 35 percent that reflected the increase in the compulsory leaving age from 15 to 16. Comprehensive schools grew at the expense of modern and grammar schools, as shown in the declining enrolment rates of the former from 25 to 5 percent and of the latter from 14 to 4 percent, between 1965 and 1979. The important turning point in this period is the ratification of the 1976 Education Act by the Labour party, which aim to effectively abolish the selective system by requiring LEAs to abolish grammar schools.

The distribution of pupils by educational track set in the early 1980s set the trend for the remainder of the third period (1980-1993). By then, more than half of pupils in England and Wales were enrolled in comprehensive schools, reaching a height of 55 percent in 1985, declining slightly to 52 percent in the late 1980s, and rising again to 56 percent by 1993, the last year in which data by track is available. Modern schools practically vanished, falling to a floor of 2 percent, while grammar schools suffered a similar fate. The one main innovation visible during this period is the growth of middle schools, schools bridging the primary and secondary distinction, created for pupils aged 10-13 or 10-14. These schools cropped up during the late 1960s, and by 1970 there were around 100 such schools, although enrollment data is not available. However, such schools never incorporated many pupils, partly because of the incentive to structure education around the key distinction of primary and secondary levels and the key ISCED stages, and so exhibit a gross enrolment rate that is around 4 percent for the entire third period.

\subsection{Expansion of the Upper Secondary Schooling - Policies vs. Market}

The enrolment rate has been responsive to two types of policies which affect the structure and comprehensiveness of education (Toubeau 20012). Type 1 policies tend to have a powerful effect on enrollment, while Type 2 policies create a framework in which demographic and economic variables can find an outlet and thus yield a more gradual effect on enrollment rates. A typical example of Type 1 policy is an increase in the compulsory leaving age, which effectively enforces all children up to a certain age to participate in education. The case of the United Kingdom is a good illustration of immediate effects of this type of policy on enrolment. Shifting the compulsory leaving

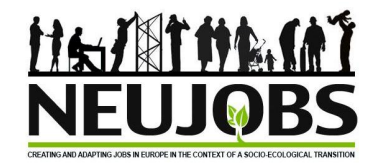


age to 15 provoked a sudden and sharp increase in the NER for the 11-14 age category in the late 1940s from 78 to 92 percent; establishing the division between education levels at 11 generated a sudden and significant decline in the NER from 68 to 21 percent for primary schools in the late 1940s. The change in the CLA in 1972 had a similar effect at the USE level: there was a sudden and significant shift in the NER from 28 to 44 percent in the space of year. This effect was visible in particular in the share enrolled in comprehensive schools, where the NER doubled form 11 to 22 percent. Thus, we can conclude that the NER is highly sensitive to policies aiming to change the structure of education, which affect the CLA and the cut-off age between levels.

However, the case of Spain illustrates that the shift in the compulsory schooling age may have unexpected consequences in the form of higher dropout rates, especially when the curriculum does not reflect different cognitive abilities of students (Marchesi 1992: 597). Although the 1990 reform of the Spanish educational system (LOGSE) made the secondary education compulsory up until the age of 16 (same as in the United Kingdom), the expansion of the secondary schooling was hampered by low completion rates, which reach the value of $62 \%$. These low completion rates reflect the high proportion of early school leavers. The percentage of the student population that stays in school until 18 years of age is $70 \%$, which is far behind other countries in the European Union (Enguita et al., 2010). School dropout rates are double the European average. Furthermore, the dropout rates begin to rise already at the lower secondary level. Although they fell from $41 \%$ in 1992 to $29 \%$ in 2000 , they began to slowly rise thereafter, reaching $31 \%$ in 2009 (Las cifras de la educación). School dropouts are twice as high as the one of the average European Country. High dropout rates are reflected in a low percentage of youth having an upper secondary education certificate compared to the European average (Enguita et al., 2010). From 1992 to 2000, in only 8 years, dropout rates in lower-secondary education fall from $41 \%$ to $29 \%$, while from 2000 dropouts begun to slowly rise, reaching $31 \%$ in 2009 .

In the Survey on the Transition from Education/Training to Labor Market Insertion (ETEFIL) carried out in 2005, half of students declared that they dropped out of secondary schooling because they did not want to study, whereas one third of students dropped out because of labor market expectations (Enguita et al. 2010). Labor market expectations seem to be particularly important in case of students in vocational training, who have greater chances of finding a job even before finishing their training. Furthermore, there is a gender divide: whereas males cite labor market expectation more frequently, rejection of further study is more common among the females. The parental socioeconomic background is a key determinant in explaining dropout in secondary education. Children of highly educated parents, natives and from private and semiprivate schools are less likely to leave school early, while transitions to labor market are more likely among children of lower educated parents.

The effect of Type 2 policies is less clear, especially at the post-compulsory level. There were three major educational reforms in the United Kingdom. The 1944 Education sought to widen educational opportunities by instituting the tripartite system and

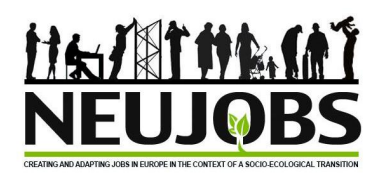


abolishing tuition fees for grammar schools. The consequences of the Act were visible at the lower secondary level: there was clear separation between modern and grammar schools, with modern schools taking the bulk of students. The gross enrolment rate for modern schools experienced a gradual but significant expansion between the late 1940s and early 1960s, from 42 to 56 percent, reflecting the consequences of demographic growth and rising wealth. The consequences of the Act for the upper secondary level are less evident: grammar schools rather than modern schools took in the bulk of students, reflecting the fact that school after 15 was left for the privileged or the academically able. Both grammar schools and modern schools experienced a gradual growth during the 1950s, reflecting increasing population growth and economic affluence, but it was less significant that at the USE level both in absolute and relative terms. The sensitivity of gross enrolment rate across different tracks to socio-demographic variables is thus visible for both the LSE and USE, but to a weaker degree in the latter.

This conclusion is corroborated when looking at the effects of the 1965 Circular and at the 1976 Education Act, both of which sought to expand educational opportunities by abolishing the selection. The introduction of the 1965 Circular is associated across levels with an important but gradual increase in the gross enrolment rate for comprehensive schools and with a gradual decrease in the gross enrolment rate for modern and grammar schools, though the latter are affected in a different sequence and to different degrees depending on whether we look at the lower and upper secondary levels. At the lower secondary level, this reflected both a population growth and a simple switch between tracks, since the gross enrolment rate for that age category was 100 percent by the late 1950s; at the upper secondary level this reflected both a population growth, a rise in GROSS enrolment rate for the age category from 25 to 45 percent between 1965 and 1975, as well a switch between tracks. This trend persists after the passage of the 1976 Act, but again, the effects on the GER across tracks and level are gradual.

It is therefore possible to conclude that i) that the effect of these policies was not direct; these policies created the framework in which demographic growth, economic growth, and rising educational aspirations could find an outlet, engendering a gradual pattern of expansion; ii) that their effect depended primarily on the level of education, with important differences visible between the lower secondary education, in which education is compulsory, and the upper secondary education, in which education no longer is compulsory.

Strong impact of the shift in compulsory leaving age is documented also in case of Sweden. By the end of the Second World War, the enrolment rate in upper secondary education was $43.5 \%$. The year of the 1960 Education Act, which established the 9 year compulsory primary school, the enrolment rate had risen to $52.8 \%$. By 1968 with the adoption of the upper secondary school reform and the replacement of parallel schools with the integrated gymnasieskolan the enrolment had increased to 63.6\%. In 1980 the enrolment rate shows practically universal participation in upper secondary education, 80.3\%, although the enrolment rate would go down during this decade. The 1991 education reform involved the full universalization of upper secondary education with 
municipalities obliged by law to offer upper secondary education to all young people between 16 and 20 who had finished primary education. In 1991 the enrolment rate was $88.0 \%$ and ten years later the enrolment rate was $100 \%$-and even more due to the number of older students making up for upper secondary education, often with the aim of continuing to tertiary studies. The percentage of upper secondary student enrolments in vocational tracks has shifted since the 1991 reform, and increased in the last decade: $49 \%$ in 1992, 41\% in 1998, 53\% in 2005 and 55\% in 2009 (OECD 2011; Kuczera et. al. 2008).

Strong impact of the shift in the compulsory leaving age and reorganization of schooling is documented also in case of Czechoslovakia. Prior to the reform of 1948, students had three options at the end of the eight-year compulsory primary school. They could enter the labor force, obtain vocational training or continue on to academic schools. Majority of students chose on of the first two options (von Kopp 1988). Only about one-quarter of the Czechoslovak population who reached secondary-school age before 1948 progressed from primary to secondary schools, which culminated in a "maturita" examination, which, if passed, provided individuals with the credentials necessary to gain admission to universities or tertiary institutes (Hanley 2001: 28). In 1948, the educational system was restructured in line with the Soviet model. A single and uniform school covering the whole compulsory education period was introduced in 1948. The tripartite system of upper secondary education based on the European continental model was maintained at the upper secondary level: secondary general schools (gymnasium), secondary technical schools and vocational schools. The 1948 education law prolonged compulsory education by one year to the age of 15 . However, the compulsory education did not end at this age because students who did not continue their education at gymnasiums or technicums had to continue their studies at vocational schools (Ván̆ová 2007: 84). In 1948, the gross enrolment ratio jumped to $45.1 \%$.

The post-communist period enables us to examine the inability of policy-makers to implement policies. Following the collapse of the communism, educational reforms in both the Czech Republic and Slovakia recommended expansion of the upper secondary attainment, especially regarding general educational tracks, whose expansion had previously been restricted. Slovak strategic document "Konštantín" (1994: 10-11) recommended to increase the proportion of students leaving secondary schools with the "maturita" exam from $48 \%$ to $80 \%$ of 18 -year old population by 2010 , to increase the proportion of population with upper secondary attainment from $53 \%$ to $63.3 \%$ and to increase the proportion of newly enrolled university students from 11 to $30 \%$ of 18 -year old population by 2010. The subsequent strategic document "Milénium" (Ministerstvo školstva 2002: 13) emphasized that only $16.8 \%$ of students were enrolled in general tracks. This share was the lowest among EU and EU-accession countries, apart from the Czech Republic. "Milénium" also pointed out that Slovakia was poor in natural resources and human resources were the most important source of the future prosperity of the country. It was therefore recommended to increase the educational attainment of Slovak population. The proportion of students accepted to university studies was supposed to increase from the current $25 \%$ to $30 \%$ by 2002 and $35 \%$ by 2015 , the proportion of graduates with "maturita" exam was supposed to increase to $80 \%$ by 2010 , the share of students enrolled in gymnasia was supposed to increase from the current $17-18 \%$ to $25-30 \%$ of the corresponding age cohort and the compulsory

\section{NEUJOBS}


education was supposed to be prolonged (ibid: 19-20). On a similar note, the Czech National Programme for the Development of Education in the Czech Republic (Institute for Information on Education 2001: 55), known as the White Paper, supported the development of generally oriented educational programmes, so that they can accommodate at least 30\% of young people in upper secondary education by 2005 . Furthermore, the expansion of the upper secondary education was supposed to encompass all tracks: with the promotion of extension courses enabling students completing vocational training to pass "maturita" exam, the proportion of population leaving secondary schools with the "maturita" exam as the school leaving exam was supposed to increase to $75 \%$ of population by 2005 (ibid). None of these declaration was translated into meaningful policies. Nevertheless, the expansion of the general sector did occur, mostly thanks to the working of the market forces.

During the communism, the centralized educational system coupled with quotas on seat in general tracks enabled the Communist Party to manage distribution of students across tracks. Preference was given to vocational and technical over general tracks. The tight management did not trigger many protests. First, the link between education and wages was broken and students did not have incentive to pursue academic tracks. Second, academic tracks were not a sole educational path leading to university studies. Technicums culminated in "maturita" exams as well and students of vocational tracks were allowed to enter universities after taking further courses at technicums. The situation changed dramatically after the collapse of the communism. Once the link between education and wages was restored, expansion of upper secondary education was re-directed towards general tracks leading to university education. The movement towards more general tracks happened on its own, supported by a number of private schools, which began to spring to life to meet excessive demand for this type of schooling.

At this stage of expansion, the policy-makers began to worry about the decline of vocational schooling. However, freedom to establish schools coupled with oversupply of seats in all tracks made it very difficult to divert students back to vocational tracks. Once again, it was market forces, which increased demand for vocational and technical schooling. However, increased enrolment in vocational and technical tracks was limited to regions with large investment by car producing factories.

In contrast, Swedish policy makers were more successful in promotion of the vocational education. The 1991 reform of upper secondary education introduced a further integrated, three-year long upper secondary school. The differences between academic and vocational upper secondary education were reduced; all the vocational and academic programmes included a substantial common core of general subjects and both academic and vocational tracks provided general eligibility to enter higher education. The Swedish Employers' Confederation SAF and the Swedish Trade Union Confederation LO, actively promoted a reform aimed particularly at the modernisation of vocational education at upper secondary level. The Education Act from 2010 that came into force in 2011 sought a clearer separation of academic and vocational programs. The percentage of upper secondary student enrolments in vocational tracks has shifted since the 1991 reform, and increased in the last decade: from 49\% in 1992,

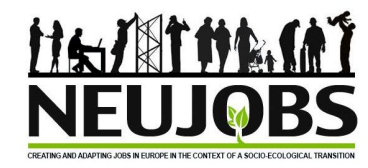


to $41 \%$ in 1998 and $55 \%$ in 2009 . Hence, in the Swedish case we do not observe a clear decline of vocational tracks relative to academic in this final expansion stage of upper secondary education.

As already noted above, the vocational schooling is popular also in Germany. From the policy perspective, it is possible to attribute it to the failure of reform attempts seeking abolishment of the traditional tripartite structure, in which children are selected into academic Gymnasia and vocational tracks at an early age.

The freedom of right to establish schools may pose a challenge to the enforcement of the schooling quality. Following the collapse of communism, the quality of rapidly emerging private upper secondary schools was contested in both the Czech Republic and Slovakia. School inspectors believed that some parents sign their children to private schools in expectation of less strict entry and graduation criteria. Quality of private schooling seems to be highly polarized. Private schools tend to be both the best and the worst performers. Whereas the former aim to provide more education for more money, the latter attract their student body by offering easy access to educational certificates. It is reasonable to assume that the same type of polarization will accompany the expansion of private tertiary sector, especially if there is lack of control mechanisms. Finally, the case of Spain suggests that it is easier for the state to control the private sector, when the privately-owned schools are publicly financed.

\subsection{Bachelor's Degree as an Extension of the Upper Secondary Education?}

As the enrollment rates in upper secondary education began approaching universal levels, we observed two trends. First, the case of the Czech Republic and Slovakia documents that the universalization of the upper secondary education was associated with the falling demand for part-time upper secondary and part-time post-secondary non-tertiary education. At the same time, the demand for the flexible, part-time study spilled to the higher education: approximately one third of students was enrolled in these type of programs by 2010 . The bachelor level may thus gradually replace postsecondary non-tertiary education. We observed a similar trend in case of the British further education: whereas the enrolment in further education in the age cohort of 19-23 rose from $4.9 \%$ in 1953 to approximately $21.6 \%$ in 1986 , it reached only $11.5 \%$ in 2009.

On a similar note, the generalization of the upper secondary track, which occurred in the post-World War II period, seems to have spilled into the Bachelor studies. The actual specialization is taking place only in the last year of the Bachelor and especially during the Master and PhD. Zymek (188 et seq.) sees in this a development in which the Bachelor is becoming the extension of upper secondary studies, offering a general education and preparing students either to professional life or to further university studies. In this, the expansion of upper secondary education might have a direct impact on the expansion of tertiary education. Zymek argues that, the Bachelor as the first level of higher education might go through a similar development to the one that the Gymnasium experienced, moving from an elite institution to something close to a mass 
institution. Consequently, in the near future it might be rather the master studies, and even more so, the $\mathrm{PhD}$, which will be reserved to an academic elite only.

\section{Conclusions}

In this paper, we presented the historical time series of gross enrolment rates in Czechoslovakia, Spain and the United Kingdom. Our study was complemented by the existing historical time series of gross enrolment rates in Sweden and Germany, to control for expansion of schooling in countries at the opposing poles of educational stratification. The presented data were examined in light of reform attempts aimed at expansion of schooling with the aim to derive lessons for the expansion of the tertiary sector. Our research questions about the speed and differentiation of expansion of the upper secondary schooling were thus motivated by the fact that expansion of the general upper secondary schooling is a prerequisite for the expansion of the tertiary education. Our findings are as follows.

First, upper secondary sectors expanded at different speeds. The expansion was relatively slow in the leaders, such as the United Kingdom. In contrast, upper secondary sectors that were kept artificially small, such as Spanish educational sector under Franquist regime, expanded rapidly once the limiting condition was removed. Our results suggest that universalization of upper secondary sector was faster than universalization of the primary or lower secondary schooling. Wils and O'Connor (2003a) proxy enrollment with literacy acquisition and find that the typical country in the postwar 20th century took 35-80 years to make a transition from $10 \%$ net primary enrollment to $90 \%$. Clemens (2004) used a more precise proxy, i.e. the number of people of any age enrolled in primary school divided by the size of the population under the age of 15 , analogous to but not precisely equal to gross enrollment (the denominator includes infants). His results imply that the typical country after 1960 took about 28 years to get from $75 \%$ of the worldwide maximum level of that enrollment statistic to $90 \%$ of the maximum. Before 1914 it took about 41 years to get from $75 \%$ of the worldwide maximum value of net primary enrollment to $90 \%$ of the maximum.

As the enrollment rates exceed $80 \%$, we observe two trends. First, the demand for parttime secondary or post-secondary non-tertiary education declines and the demand for flexible forms of more prestigious tertiary education rises. Second, the generalization of the upper secondary schooling seems to have spilled to the bachelor studies. For example, in Germany, the specialization occurs only at Master or PhD level (Zymek 2009).

Second, over the past sixty years, the general education tended to grow at the expense of vocational education. The general to vocational program ratio rose the most rapidly in the post-communist Czech Republic and Slovakia, where it had been kept artificially low during the communist regime. Once the links between the wages and education were restored, the demand for tracks leading to university studies rose rapidly. Although the demand for vocational schools and technicums rose following the arrival of foreign automotive companies, this increase was only regional. This suggests that the pool of students eligible for the tertiary studies has grown both as a result of expansion of the general track and elimination of dead-end educational pathways

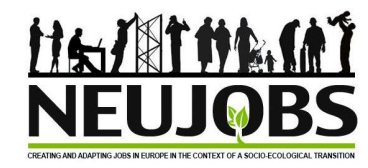


However, it must be noted that the position and popularity of vocational schooling has been diverse across countries. Vocational tracks remained popular or regained some of its popularity in Germany or Sweden. In Germany, the strength of the vocational education may be attributed to the existing highly stratified tripartite system, in which students are selected for general or vocational study at an early age. Although there have been attempts to eliminate dead-end educational pathways, the mobility across tracks is low and usually directed from general to vocational tracks, rather than vice versa. Nevertheless, vocational students are able to enroll to universities after successful completion of their education in intermediate tracks. Trends to increase opportunities to enroll to universities for students from all tracks have been universal across all examined countries.

Third, enrolment in upper secondary schooling expanded rapidly in response to increase in compulsory schooling age. Increase in compulsory schooling age thus represents a relatively easy way to expand the schooling. However, Clemens (2004: 23, 51) points out that when today's rich countries made universal primary enrollment a national development goal, they either set the goal when they had nearly achieved universal enrollment, or took several decades to approach it. Furthermore, there seems to be a spillover from one level to another. For example, shift of the compulsory schooling age at the primary level seemed to spill over to an increase of enrolment at the secondary level. However, the effects of an increase in compulsory schooling age on expansion may be mitigated by increased dropout rates in the post-compulsory period, either as a result of low cognitive abilities or low motivation to continue studies. This has been the case of Spain.

Fourth, the emergence of quasi-markets makes it more difficult for the policy makers to manage the expansion of the schooling. Whereas it is fairly easy to direct expansion into desired tracks in centralized schooling systems, such as communist Czechoslovakia, Franquist Spain or Spain from the 1950s to the 1980s, decentralized educational systems tend to be characterized by a number of bottom-up initiatives, which can hamper implementation of the official policy. The private sector has been eager to meet the demand unmet by the public schooling sector in the post-communist Slovakia. The decentralized character of the British education system helped the expansion of comprehensive schools and at the same time enabled the survival of selective elite grammar schools, which prepare students for leading British universities.

Finally, although elite, mass and universal access to education are analyzed as sequential stages of educational expansion, they do not inevitably replace one another. Beblavý and Veselkova (2012) document examples of elite forms stubbornly surviving in the mass and universal stages (elite grammar schools in the United Kingdom, Gymnasia in Germany and multi-year gymnasia in the Czech Republic and Slovakia). These examples suggest that expansion - if not accompanied by policies aimed at greater equality of educational opportunities - will reproduce social stratification despite greater participation in upper secondary schooling. 


\section{References}

Arnman, Göran, Järnek, Martin and Lindskog, Erik (2004) Valfrihet - fiktion och verklighet. Research Report 4. Studies in Educational Policy and Educational Philosophy.

Uppsala: Uppsala University.

Beblavý, Miroslav and Marcela Veselková (2012) "From Selectivity to Universalism: The Political Economy of Pro-Equality Educational Reform.” NEUJOBS Working Paper No. 4.5.2.

Benavot, Aaron (1983) „The Rise and Decline of Vocational Education,“ Sociology of Education 56 (2): 63-76.

Bertocchi, Graziella and Michael Spagat (2004) "The evolution of modern educational systems: Technical vs. general education, distributional conflict, and growth," Journal of Development Economics 73: 559-582.

Bonal, X. (1995) "Curriculum change as a form of educational policy legitimation: the case of Spain," International Studies in Sociology of Education 5(2): 203-220.

Bonal, X. (2000) "Interest groups and the state in contemporary Spanish education policy," Journal of Education Policy 15(2): 201-216.

Bourdieu, Pierre and Jean-Claude Passeron (1977) Reproduction in Education, Society, and Culture. London, England: Sage.

Carabaña, J. (1998) "Comprehensive educational reforms in Spain: Past and present," European Journal of Education 23(3): 213-228.

Cerych, Ladislav (1997) "Educational Reforms in Central and Eastern Europe: Processes and Outcomes," European Journal of Education 32 (1) Secondary Education: State and Prospects: 75-96.

Clemens, Michael A. (2004) "The Long Walk to School: International education goals in historical perspective." Working Paper Number 37. Center for Global Development.

Collins, Randall (1971) "Functional and conflict theories of educational stratification," American sociological review 36: 1002-19.

Collins, Randall (1979) The Credential Society: An Historical Sociology of Education and Stratification. New York: Academic.

Crowson, Robert L. (1996) "Introduction and overview: the new institutionalism and the politics of reinventing the American school," in The politics of education and the new institutionalism: reinventing the American School, edited by Robert L. Crowson,William Lowe Boyd,Hanne B. Mawhinney, Routledge. 
Dahlstedt, Magnus (2009) "Governing by partnerships: dilemmas in Swedish education policy at the turn of the millennium," Journal of Education Policy 24 (6): 787-801.

Davidovitch, Nitza, Zilla Sinuany-Stern and Yaacov Iram (2012) „The Price of Success: Some Consequences of Increased Access to Higher Education in Israel,“ Cross-Cultural Communication 8 (2): 101-111.

De la Croix, David, Lindh, Tomas and Malmberg, Bo (2006) Growth and Longevity from the Industrial Revolution to the Future of an Aging Society.

Arbetsrapport/Institutet för Framtidsstudier 2006:9.

On-line: http://www.framtidsstudier.se/publikation/arbetsrapport-2006-nr-9/

Annex on-line:

http://www.framtidsstudier.se/wp-content/uploads/2011/06/appendix-2006.92.pdf

De la Croix, David, Lindh, Tomas and Malmberg, Bo (2008) "Swedish economic growth and education since 1800", Canadian Journal of Economics / Revue canadienne d'Economique 41 (1) : 166-185.

Enguita, M., L. Martínez, and J. Gomez (2010) School failure and dropouts in Spain. Obra social, Fundación La Caixa, Social studies collection (29).

European Commission (2011) "Progress towards the common European objectives in education and training (2010/2011) - Indicators and benchmarks. Available from http://ec.europa.eu/education/lifelong-learning-policy/indicators10_en.htm (Accessed 30 July 2012).

Goldin, Claudia (1998) “America's Graduation from High School: The Evolution and Spread of Secondary Schooling in the Twentieth Century," The Journal of Economic History 58 (2): 345-374.

Goldin, Claudia and Katz, Lawrence F. (1998) "Human capital and social capital: the rise of secondary schooling in America, 1910 to 1940," NBER Working Paper 6439.

Gregoire, R. (1967) Vocational Education. Paris: OECD.

Grootings, Peter (1993) "VET in Transition: An Overview of Changes in Three East European Countries," European Journal of Education 28 (2), Recent Trends in Vocational Education and Training: 229-240.

Günther, R. (1996) "Spanish public policy: From dictatorship to democracy." Estudios/Working Papers (Centro de Estudios Avanzados en Ciencias So- ciales), (84).

Hanley, Eric (2001) “Centrally Administered Mobility Reconsidered: The Political Dimension of Educational Stratification in State-Socialist Czechoslovakia," Sociology of Education 74 (1): 25-43. 
Horn, Daniel (2007) "Conservative States, Stratified Education, Unequal Opportunity," Paper prepared for the ISA RC28 summer meeting in Montreal, Canada August 1417.2007.

Kamens, David H., John W. Meyer, Aaron Benavot (1996) „Worldwide Patterns in Academic Secondary Education Curricula, “ Comparative Education Review 40 (2): 116-138.

Koinzer,T. and A. Leschinsky (2009) "Privatschulen in Deutschland," Zeitschrift für Pädagogik 55: 669-685.

Kotásek, Jiří (1996) "Structure and Organisation of Secondary Education in Central and Eastern Europe,” European Journal of Education 31 (1): 25-42.

Koucký, Jan and Pavel Černohorský (1996) "Educational Reforms in Changing Societies: Central Europe in the Period of Transition," European Journal of Education 31 (1): 7-24.

Kuczera, Małgorzata, Field, Simon, Hoffman, Nancy and Wolter, Stefan (2008) Learning for Jobs OECD Reviews of Vocational Education and Training: SWEDEN. OECD.

Larsson, Hans Albin (2011) Mot bättre vetande: en svensk skolhistoria. Stockholm: SNS

Förlag.

Levy, Daniel C. (2006) "The Worldwide Expansion of Private Higher Education: Challenges for the New Institutionalism," in The New Institutionalism in Education, edited by Heinz-Dieter Meyer and Brian Rowan. Albany: State University of New York Press: 143-162.

Lundahl, Lisbeth (1997) “A common denominator? Swedish employers, trade unions and

vocational education," International Journal of Training and Development 1 (2): 91 103.

Marshall, Catherine and Gary L. Anderson (1994) "Rethinking the public and private spheres: feminist and cultural studies perspectives on the politics of education," Journal of Education Policy 9 (5): 169-182.

Matějů, Petr and Blanka Rěháková (1996) "Education as a Strategy for Life Success in the Postcommunist Transformation: The Case of the Czech Republic," Comparative Education Review 40(2): 158-176.

McNair, John (1981) "Education in Spain, 1970-80: The Years of Compulsory Schooling," Comparative Education 17(1): 47-57. 
McNair, John M. (1984) Education for a Changing Spain. Dover: Manchester University Press.

Meyer, John W (1977) "The Effects of Education as an Institution." American Journal of Sociology 83:55-77.

Meyer, John W., Francisco O. Ramirez, and Yasemin N. Soysal (1992b) "World Expansion of Mass Education, 1870-1980." Sociology of Education 65:128-49.

Meyer, Heinz-Dieter and Brian Rowan (2006) "Institutional Analysis and the Study of Education," in The New Institutionalism in Education. Edited by Heinz-Dieter Meyer and Brian Rowan. Albany: State University of New York Press: 1-13.

Neelsen, J.P. (1975) Education and social mobility. Comparative Education Review 19, $129-143$.

OECD (2011) “Country Statistical profiles: education and training”. On-line:

http://stats.oecd.org/Index.aspx?DatasetCode=CSP2011\#

O’Malley, Pamela (1995b). "Turning point: the 1970 education act," in Education reform in democratic Spain. Edited by O. Boyd-Barret and P. O'Malley. London: Routledge, 25-31.

Opper, Susan (1989) "The integrated upper secondary school as main provider of vocational education," European Journal of Education 24 (2): 139-157.

Petrini, Francesco (2004) "The common vocational training policy in the EEC from 1961 to 1972," European Journal Vocational Training 32 (II): 45-54.

Rádio Viva (18 May 2010) “Rozdiely medzi žiakmi stredných škôl.” Správy 12:00. Accessed via Newton Media.

Ramirez, Francisco O. and John Boli (1987) "The Political Construction of Mass Schooling: European Origins and Worldwide Institutionalization," Sociology of Education 60 (1): 2-17.

Rubinson, Richard and Bruce Fuller (1992) "Specifying the Effects of Education on National Economic Growth." Pp. 101-15 in The Political Construction of Education, edited by B. Fuller and R. Rubinson. New York: Praeger).

Schneider, S. and N. Tieben (2011) "A healthy sorting machine? Social inequality in the transition to upper secondary education in Germany," Oxford Review of Education 37 (2): 139-166.

Selucký, Radoslav (1964) "Slovakian Development," Czechoslovak Economic Papers 3: 42-59.

Skolverket (2006) Beskrivande data 2006. Förskoleverksamhet, skolbarnomsorg, skola och vuxenutbildning. Rapport 283. Stockholm: Skolverket. 
Skolverket (2011) "Fristående skolors utveckling". On-line:

http://www.skolverket.se/forskola_och_skola/2.300/fristaende-skolors-utveckling1.100553

SME (21 May 2010) “Študujú za peniaze, výsledky majú horšie.” Accessed via Newton Media Database.

SME (9 April 2002) "Za socializmu sa o deti staral stat, dnes to musia robit' rodičia." Accessed via Newton Media.

SOU 2008:27 Framtidsvägen - en reformerad gymnasieskola. Betänkande av gymnasieutredningen. Stockholm: Fritzes.

Statistics Sweden (1958, 1962, 1967, 1972, 1977, 1982, 1987, 1992, 1997, 2002)

Statistical abstracts. Stockholm: Statistiska Centrabyrån.

Statistisches Bundesamt, (2000): 'Allgemeinbildende und Berufliche Schulen 1950 bis 1999. Erlaeuterungen.’ Destatis, Fachserie 11 Bildung und Kultur

Švecová, Jana (2000) "Privatization of education in the Czech Republic," International Journal of Educational Development 20: 127-133.

Szebenyi, Péter (1992) "Change in the Systems of Public Education in East Central Europe," Comparative Education 28 (1) Special Number (14): Educating the New Europe: 19-31.

Trow, Martin A. (2005) "Reflections on the Transition from Elite to Mass to Universal Access: Forms and Phases of Higher Education in Modern Societies since WWII." Institute of Governmental Studies, UC Berkeley.

TV Markíza (16 February 2005) “Kúpené vzdelanie?” in Televízne noviny.

Váňová, Růžena (2007) “Školský systém v českých zemích - vývoj a současný stav,” in Pedagogika pro učitele, edited by Alena Vališová and Hana Kasíková, 69-90.

Večerník, Jiří (1992) "Earnings distribution in Czechoslovakia: Intertemporal Changes and Interna-tional Comparison," European Sociological Review 7: 237-52.

Večerník, Jiřŕ (1995) “Changing earnings distribution in the Czech Republic: survey evidence from 1988-1994," Economics of Transition 3 (3): 355-371.

Weber, M. (1921) Economy and Society. University of California Press, Berkeley. Windolf, Paul (1997) Expansion and Structural Change:H igherE ducationi n Germany, the United States, and Japan. Boulder, CO: Westview. 
Zymek, B. (2009) 'Prozesse der Internationalisierung und Hierarchisierung im Bildungssystem. Von der Beharrungskraft und Auflösung nationaler Strukturen und Mentalitäten," Zeitschrift für Pädagogik 55 (2): 175-193. 
Figure 1: Gross enrolment rates in Spain

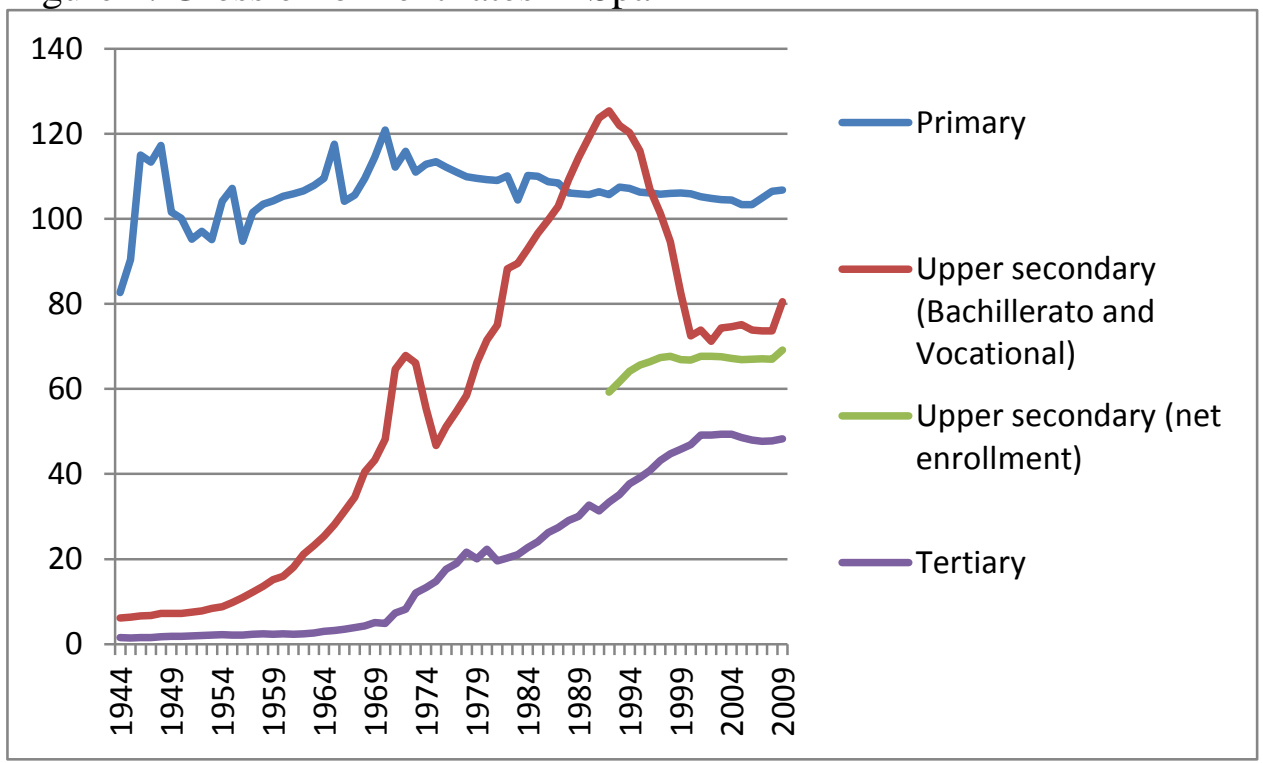

Source: Pensiero (2012) 
Figure 2: Gross enrollment rates in the Czech lands

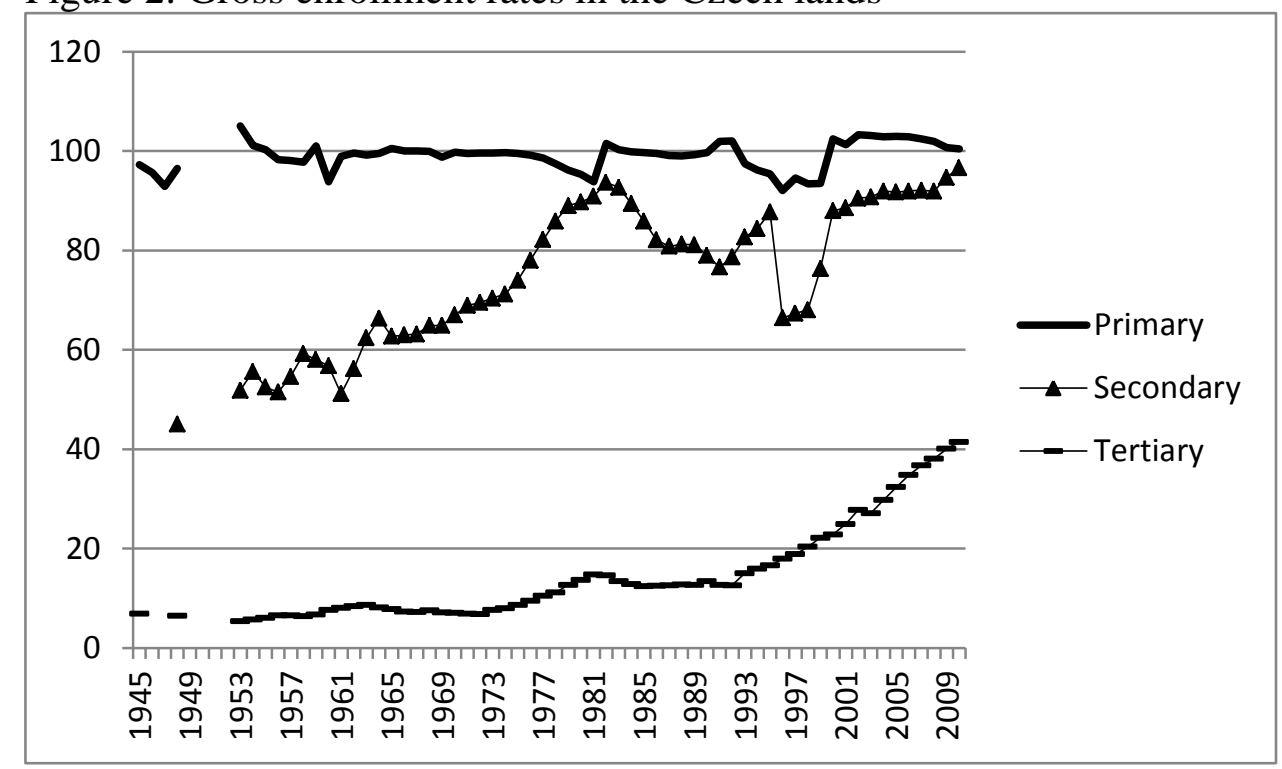

Note: Primary and secondary gross enrollment ratio is expressed as the number of enrolled students as a percentage of the official age-group for a given level of education. Tertiary enrollment ratio is the sum of full-time tertiary level students as a percentage of the mid-year population in the 5 year age group after the official secondary school leaving age. All data are reported for full-time students. Since 1990, net enrolment ratio at the primary level includes also first four years of multi-year gymnasia, which overlap with 8-9 year "basic schools". Secondary level thus refers only to students in upper secondary tracks. The dip in 1996/97 reflects the change in length of compulsory schooling when part of the children was allowed to continue their studies at upper secondary schools after the eighth grade and part of the student body remained at primary schools.

Source: Statistical yearbook of education, various years. Ústav pro informace ve vzdělávaní. Czech Statistical Office. 
Figure 3: Gross enrollment rates in the Slovak lands

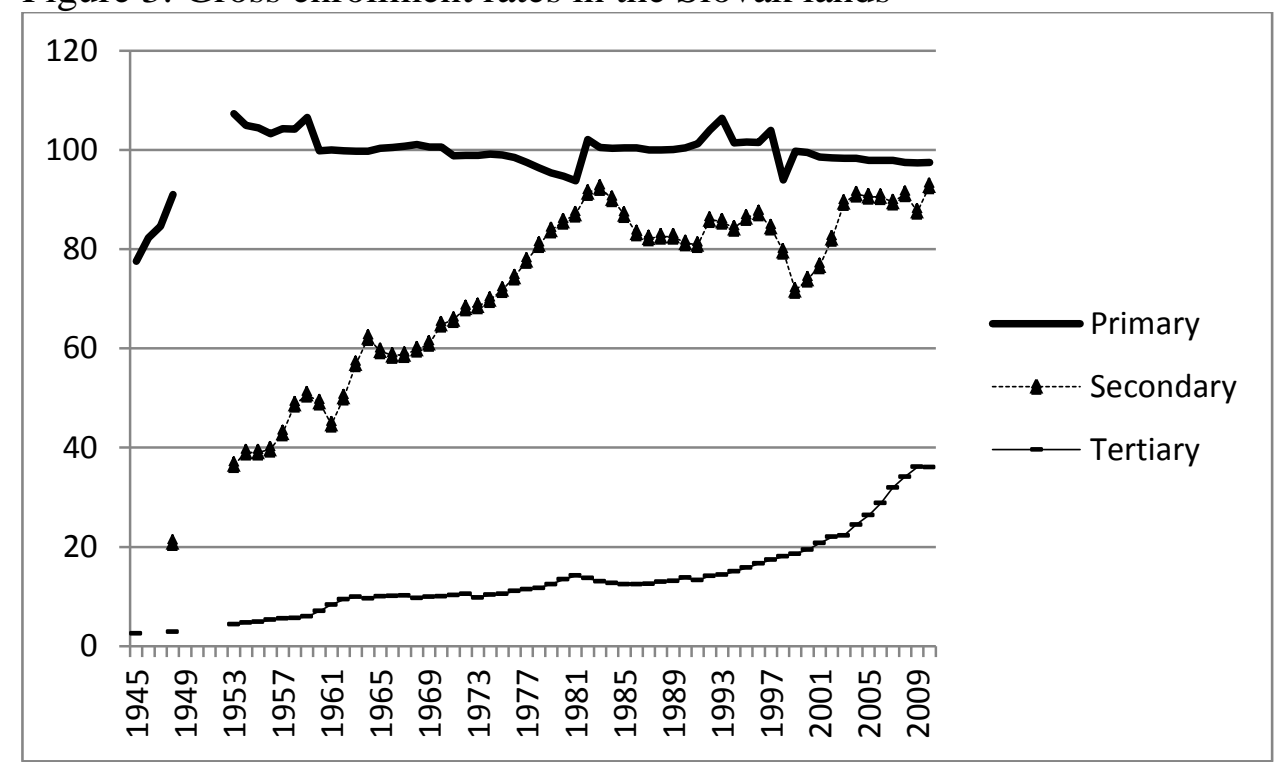

Note: see Figure 2.

Source: Statistical yearbook of education, various years. Slovstat.

Figure 4: Enrolment rates in primary, lower secondary and upper secondary (general track) in the FRG, 1950-2009, in percent

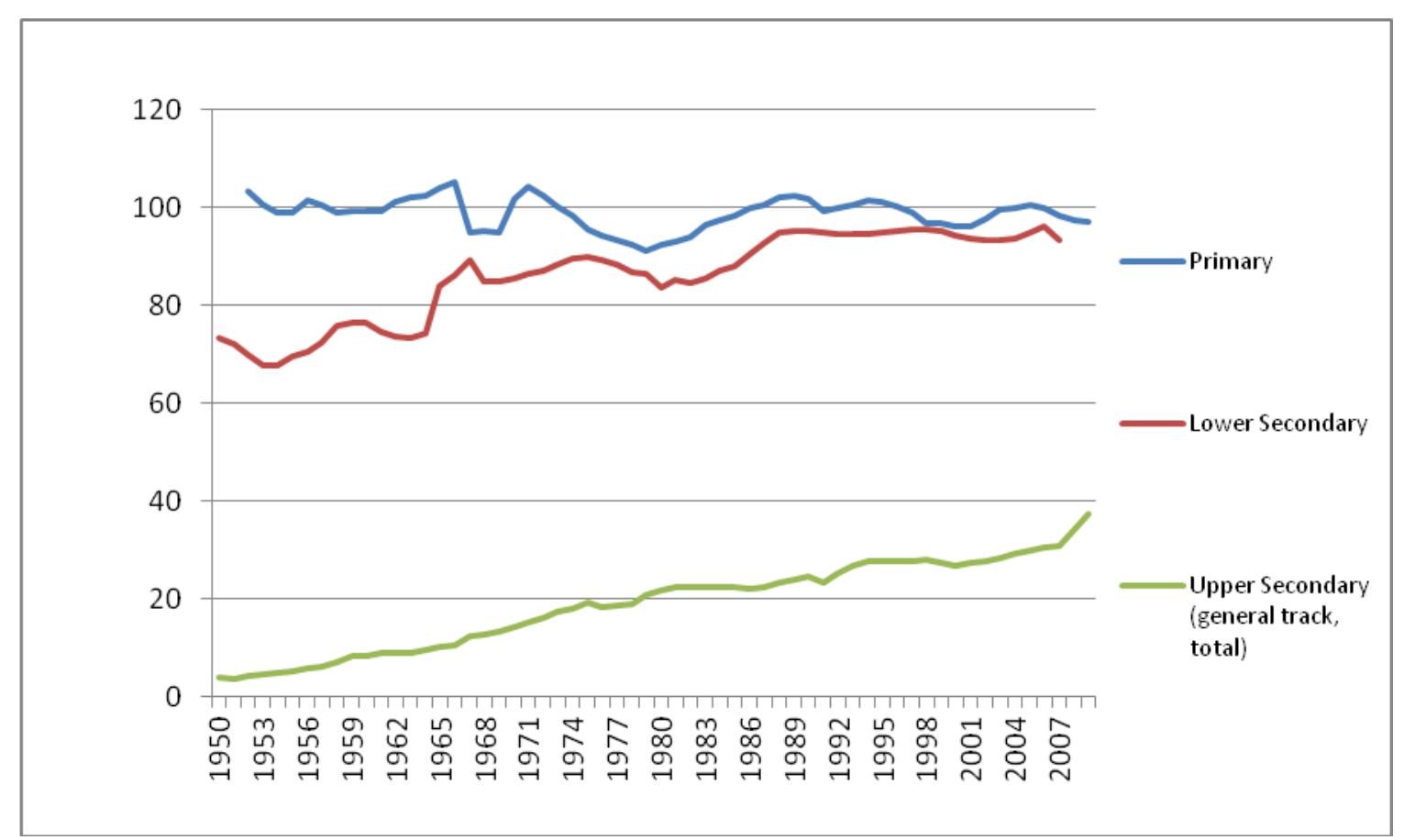

Source: BMBF, Statistisches Bundesamt, Koehler (1978,1990), EUROSTAT, own calculationsNote: The data includes enrollment in Gymnasium (yearly data available 1950-2009), Gesamtschule (yearly data available 1971-2009), Waldorf Schule (yearly data available 1980-2009) and Abendschule (yearly data available 1958-2009). 
Figure 5: Enrolment rate in tertiary education in the FRG, 1950-2011, in percent

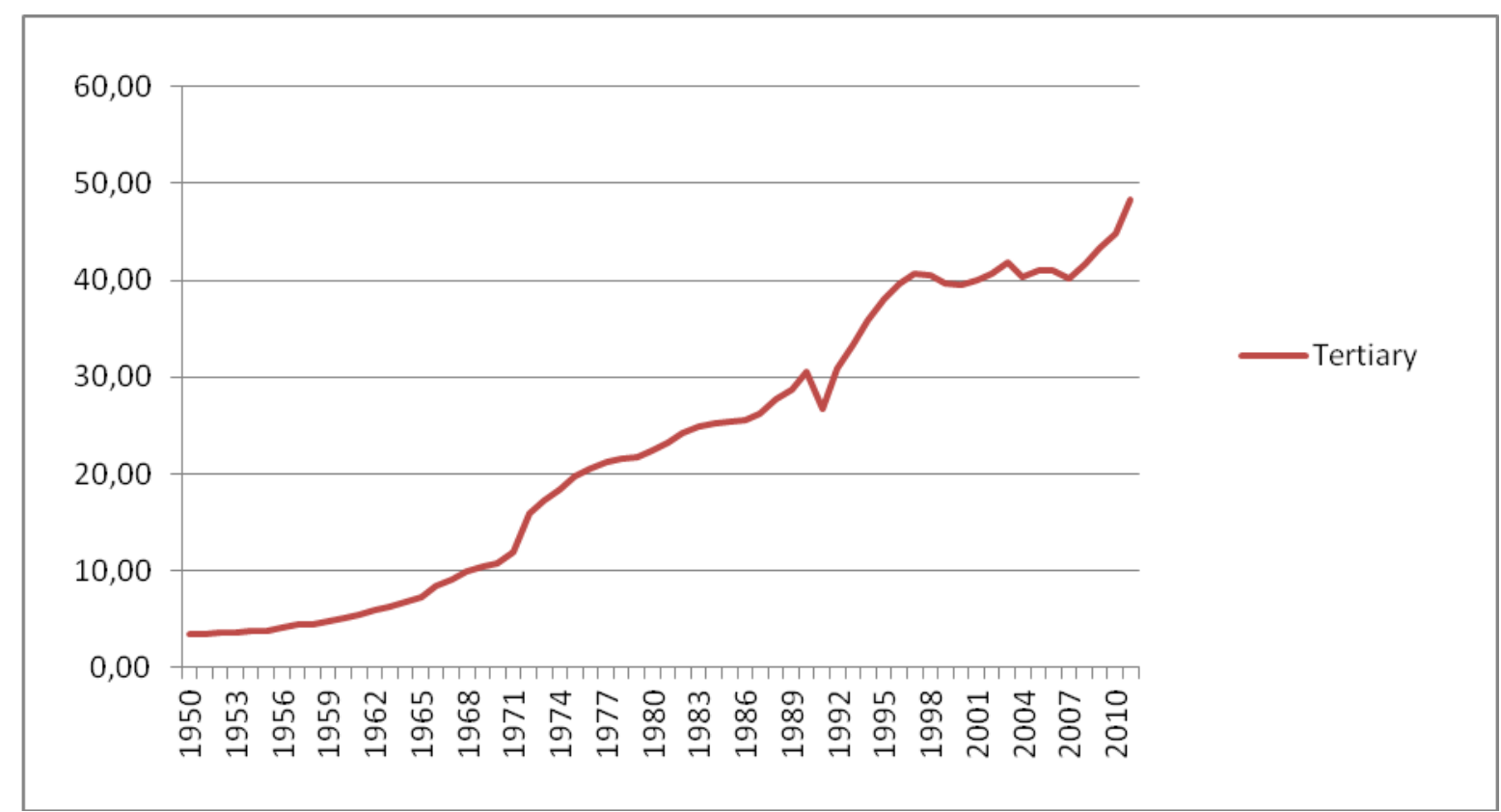

Source: BMBF

Figure 6: Gross enrolment rate, Sweden

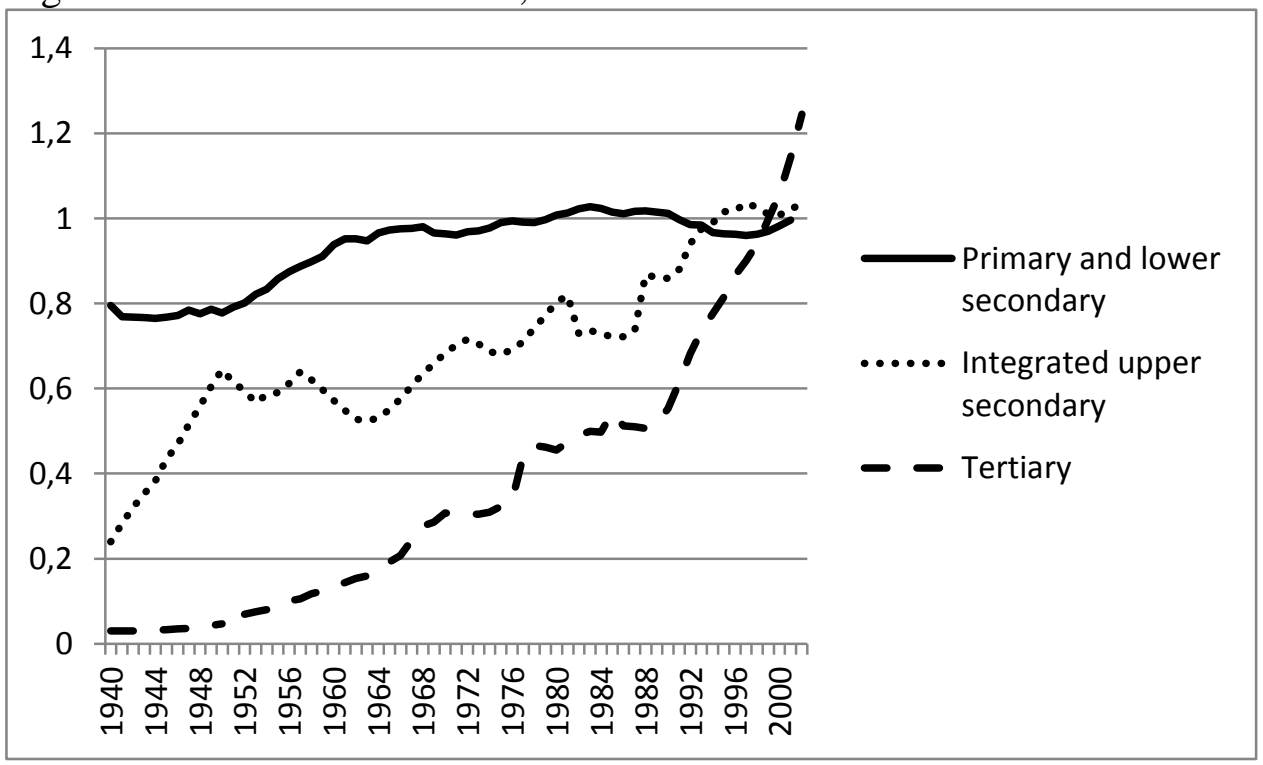

Source: Statistics Sweden Yearbooks, Historical Statistics of Sweden, Yearbook of Educational Statistics (various years). Elaborated on the basis of data presented in de la Croix, Lindh and Malmberg 2006. 
Figure 7: Expansion of primary and secondary education, by age group, England and Wales

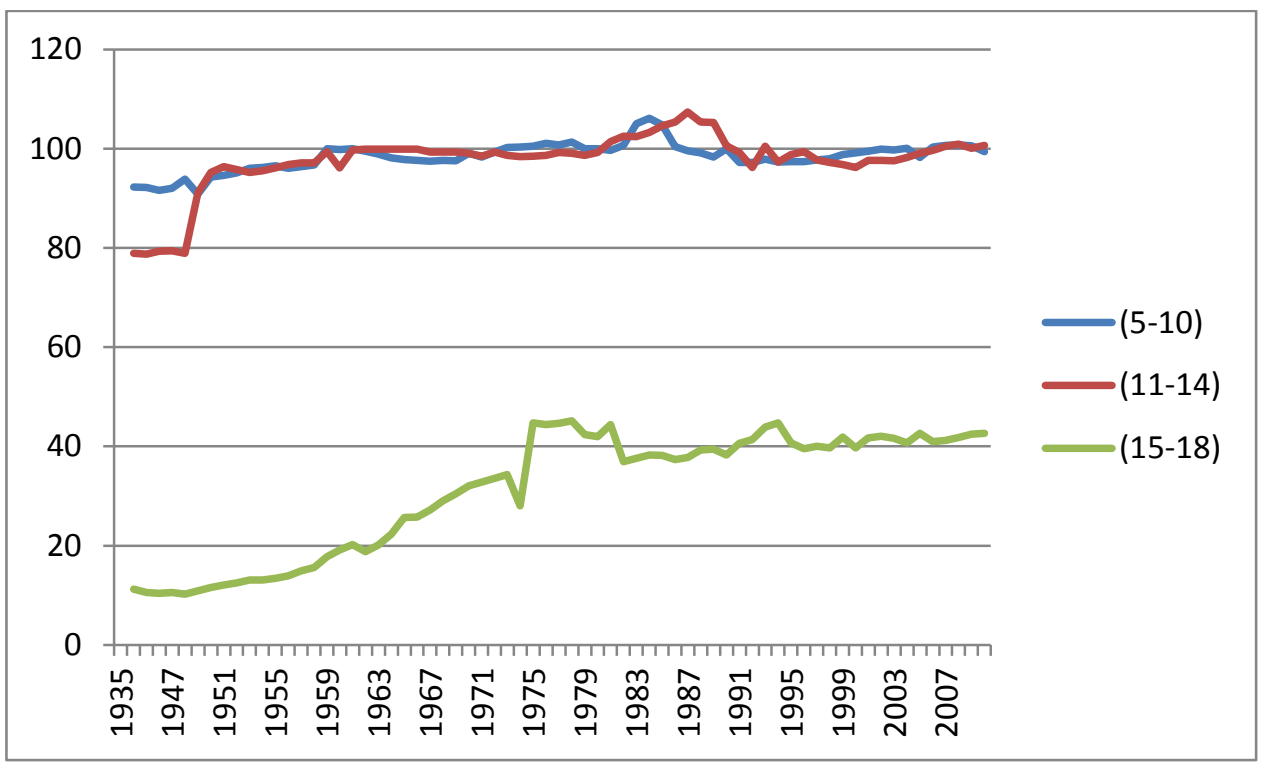

Note: Since 1998, the data refer only to England.

Figure 8: Distribution of enrolment across tracks in upper secondary level vocational education in the FRG, 1950-2009

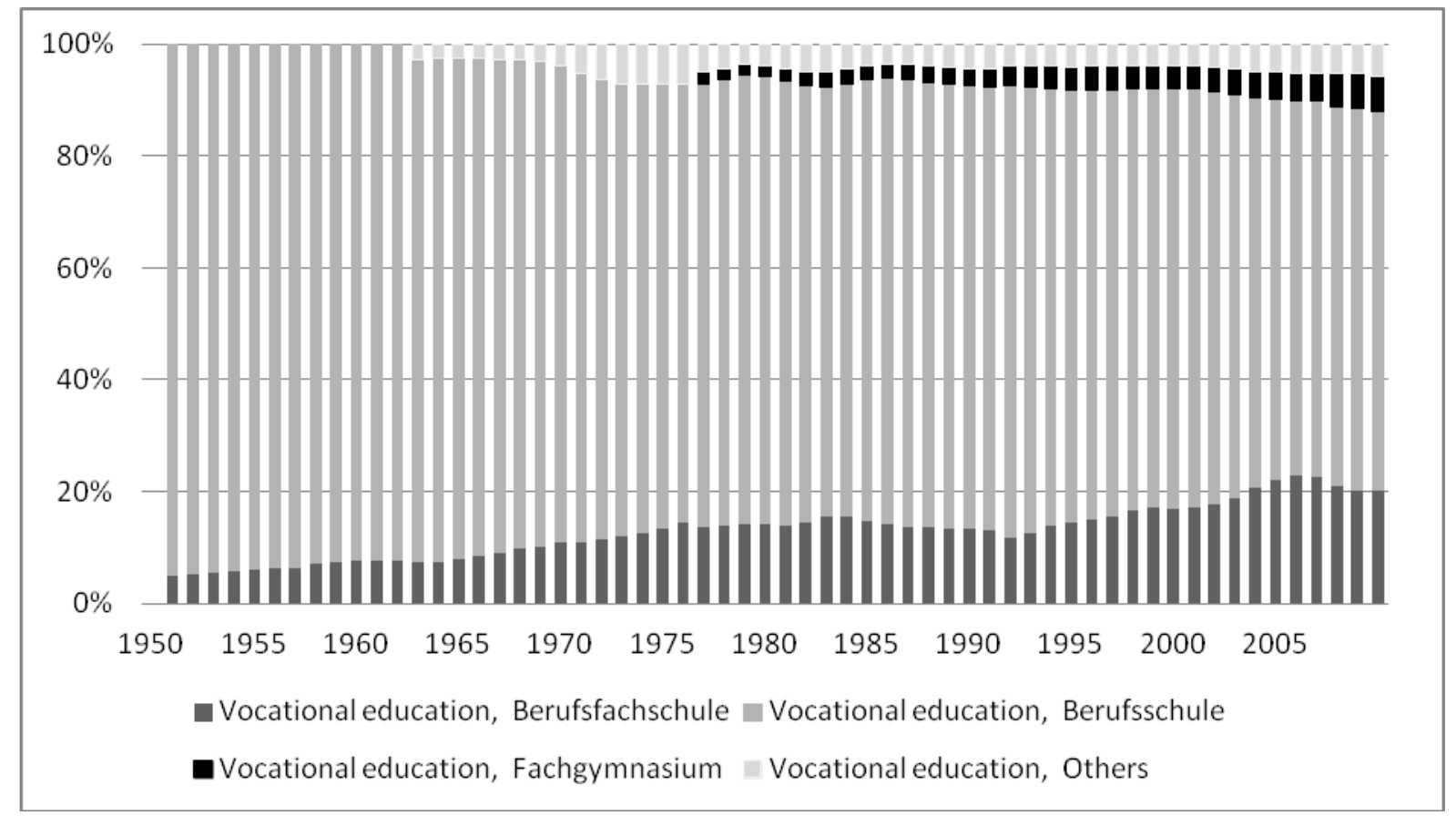

Source: BMBF, Statistisches Bundesamt, Koehler (1978,1990), EUROSTAT, own calculations 
Figure 9: Distribution of students across tracks, Czech lands.

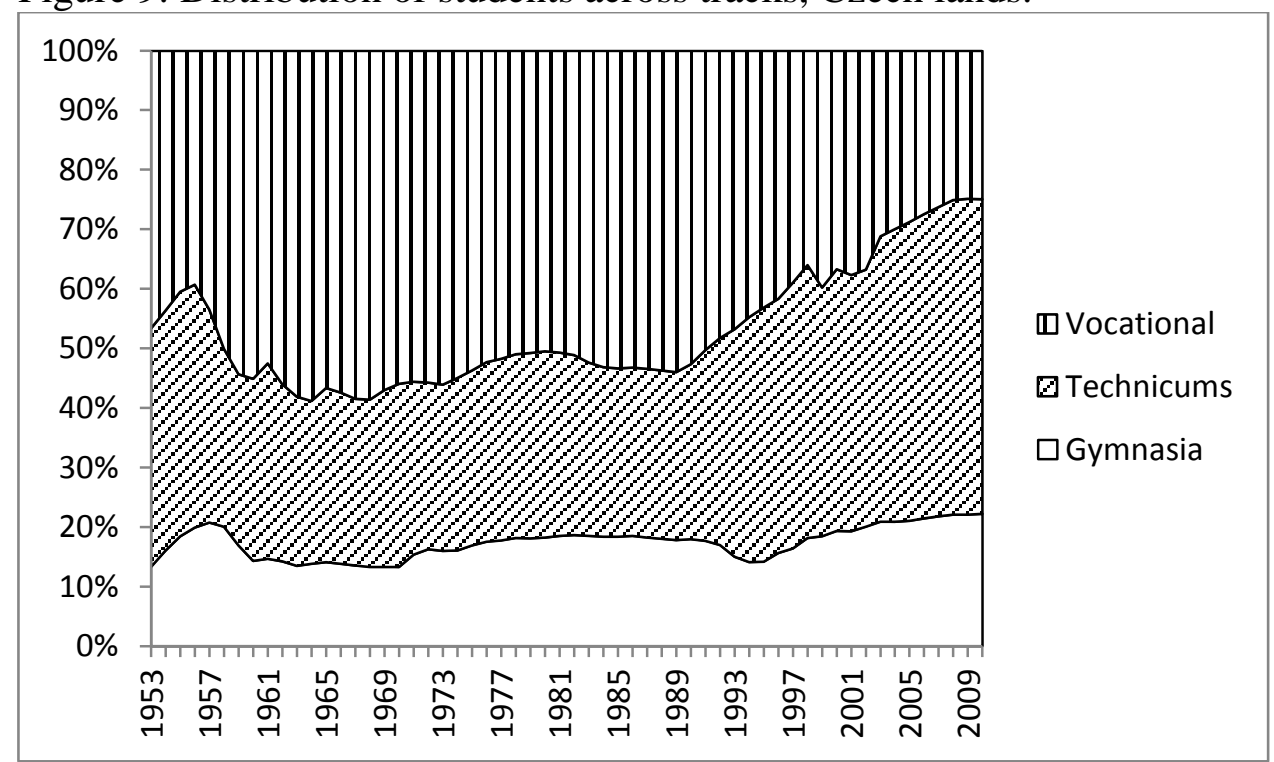

Source: See Figure 2.

Figure 10: Distribution of students across tracks, Slovak lands.

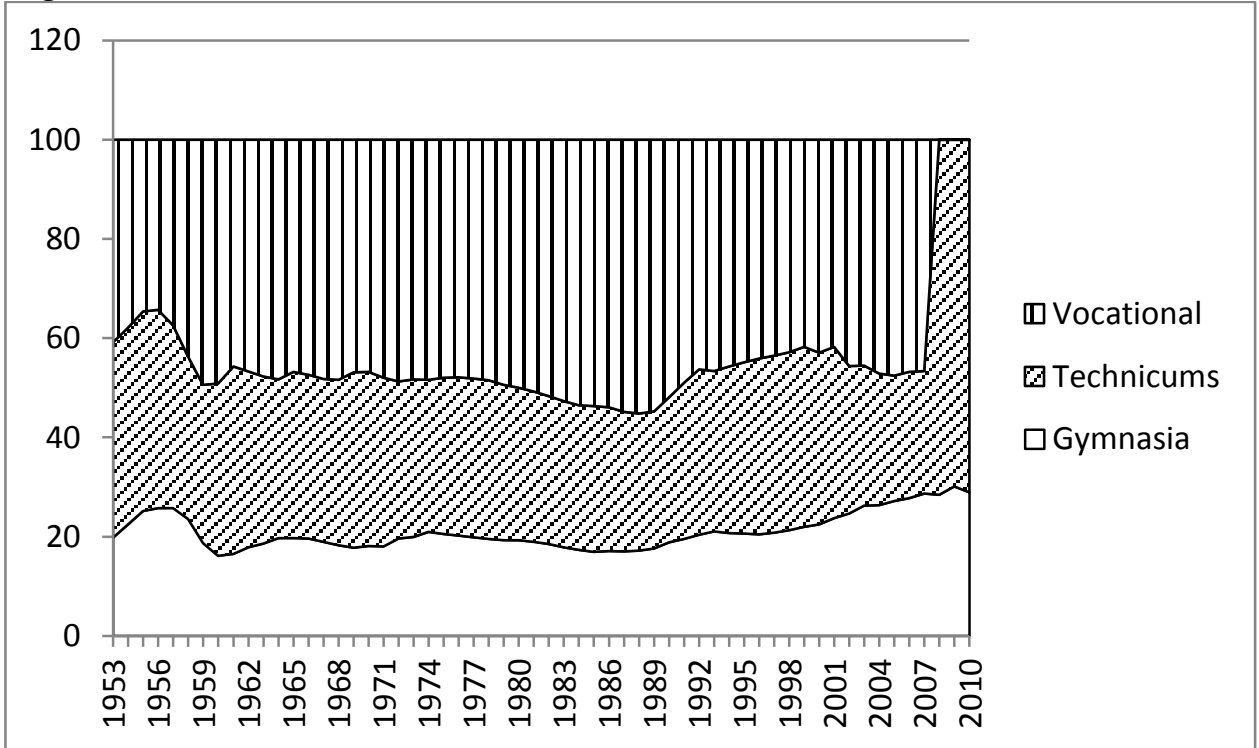

Note: In 2008 all vocational tracks were renamed to technicums ("stredná odborná škola") and henceforth reported as technicums. 
Figure 11: Trends in upper secondary level graduates 1972-1999, Sweden

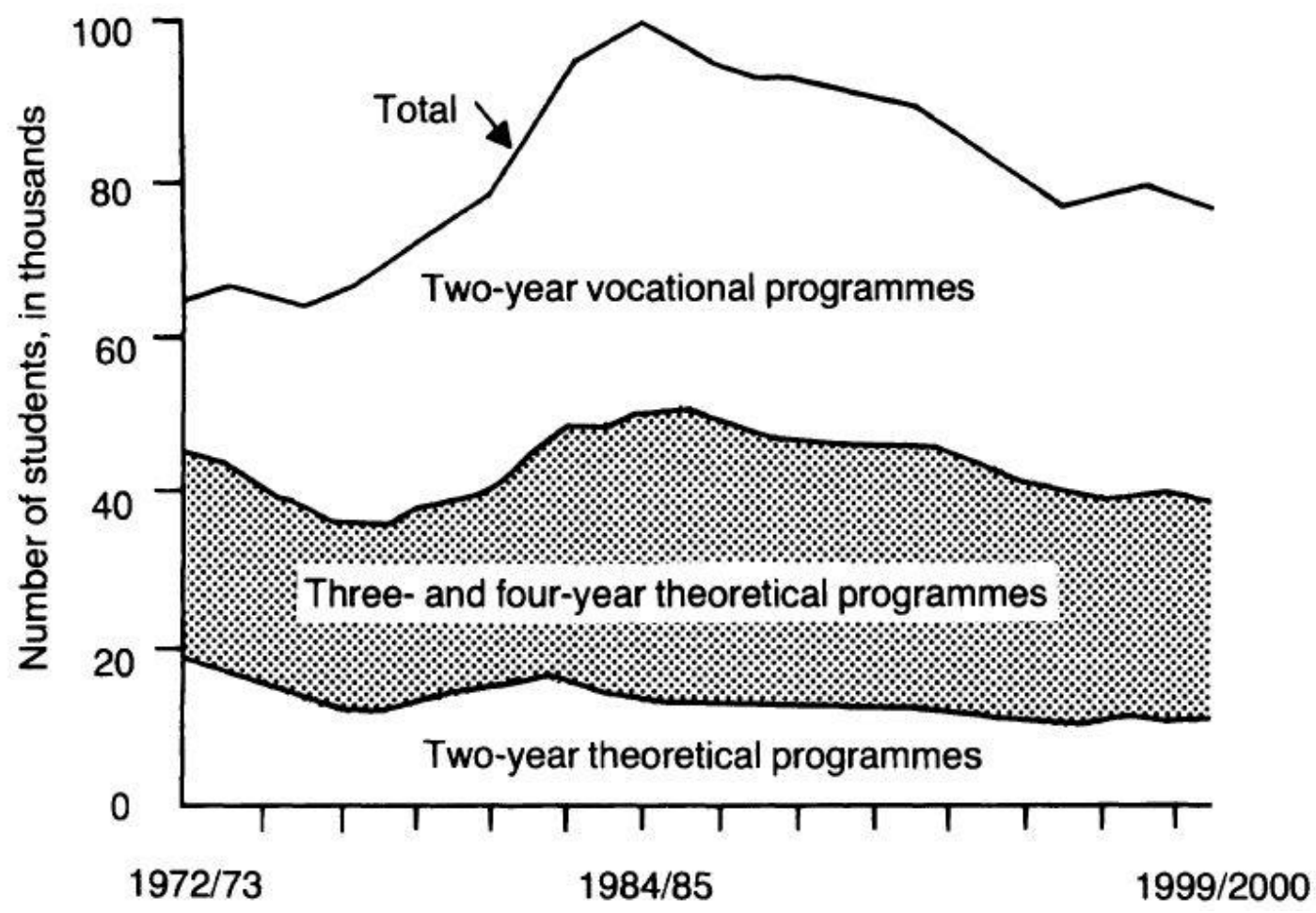

Source: Opper 1989, p. 145. 
Figure 12: Percentage of pupils in upper secondary education enrolled in vocational education, Sweden

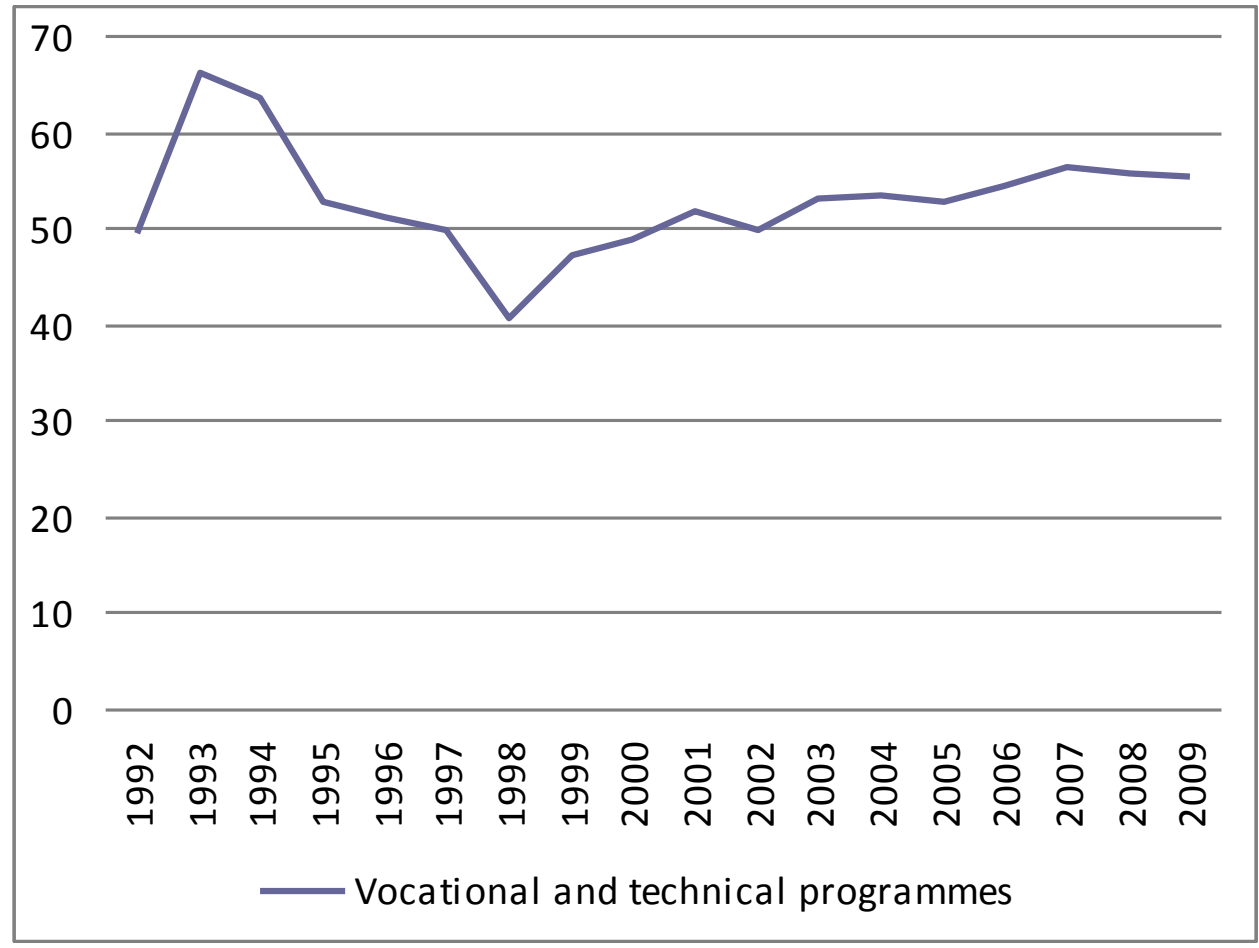

Source: Elaborated on the basis of data presented in OECD 2011

Figure 13: Gross enrolment rates by track, Spain

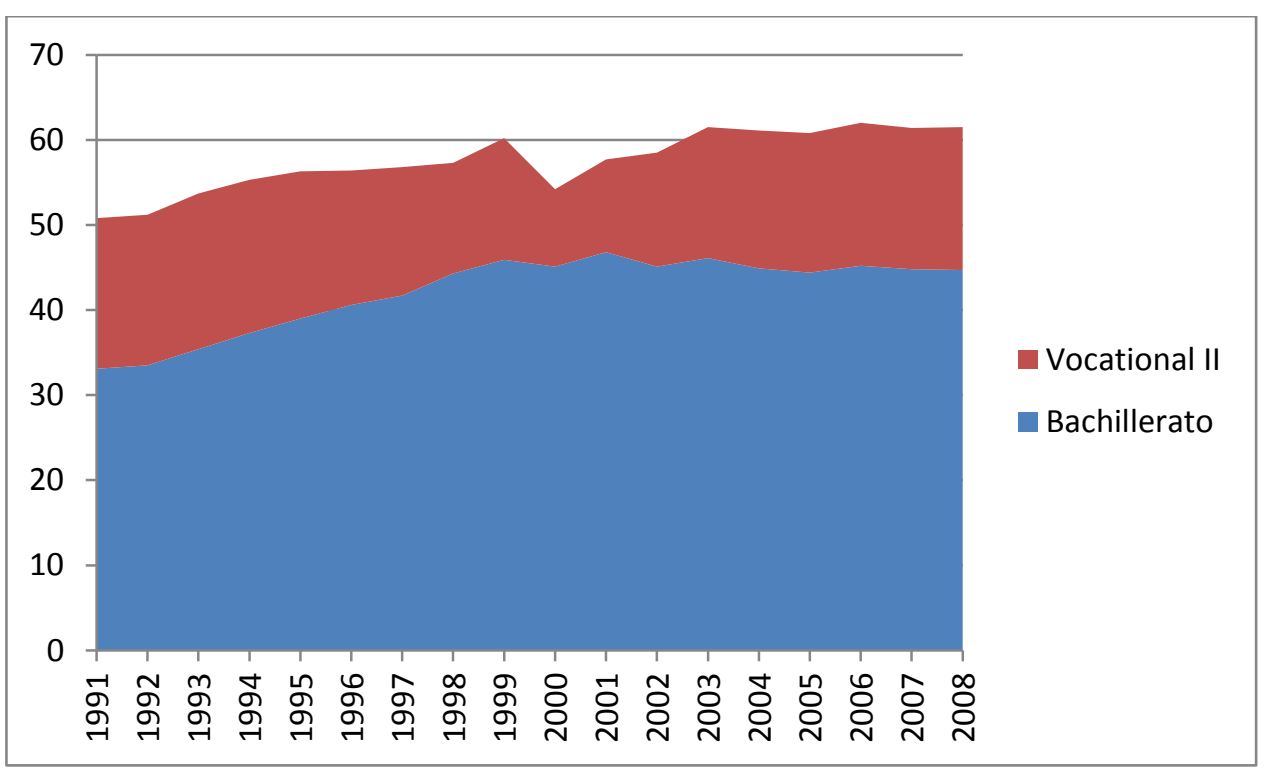

Source: Pensiero (2012) 
Figure 14: Net enrolment rates by track, United Kingdom

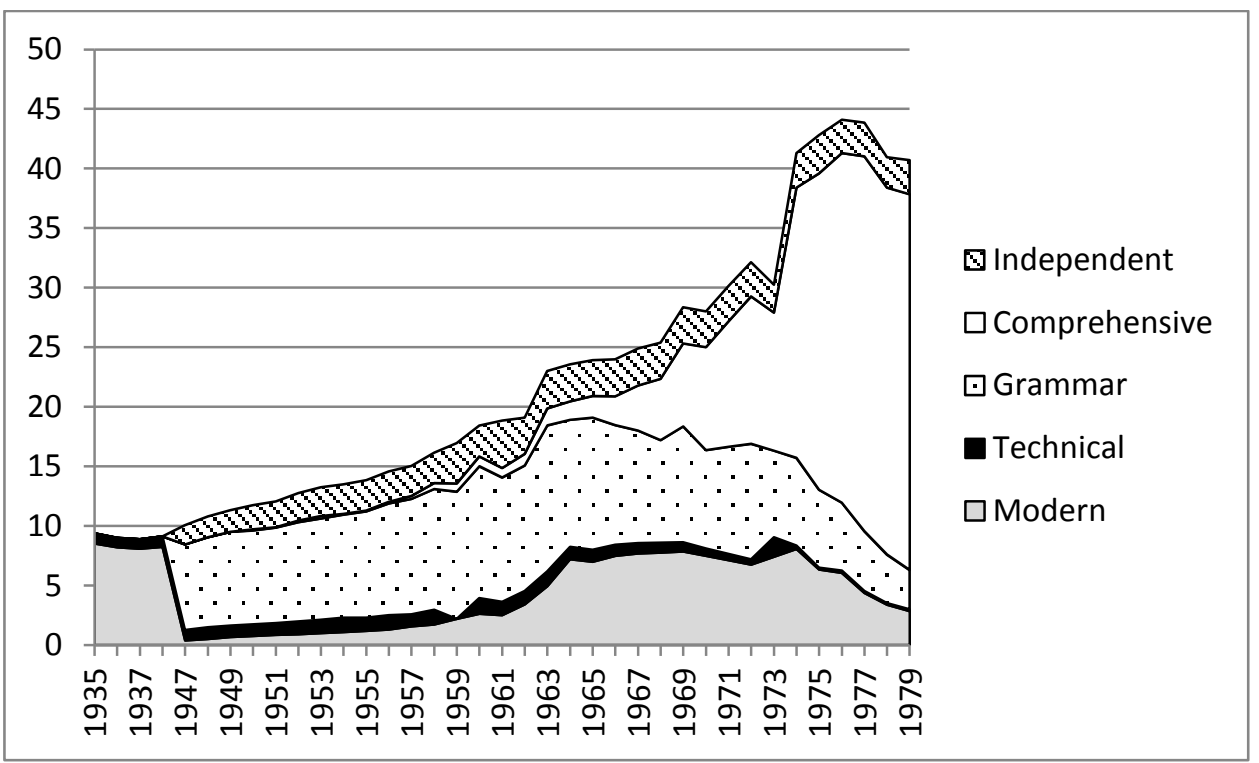

Source: Toubeau (2012) 
34 | BEBLAVY, VESELKOVA, PENSIERO, PETERSON, THUM AND TOUBEAU

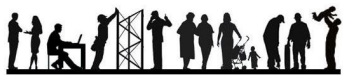 \\ NEUJOBS}


LESSONS FROM THE EXPANSION OF THE UPPER SECONDARY EDUCATION | 35

\section{Hention \\ NEUJOBS}

